NBER WORKING PAPER SERIES

\title{
BANKS AND MARKETS: THE CHANGING CHARACTER OF EUROPEAN FINANCE
}

\author{
Raghuram Rajan \\ Luigi Zingales \\ Working Paper 9595 \\ http://www.nber.org/papers/w9595 \\ NATIONAL BUREAU OF ECONOMIC RESEARCH \\ 1050 Massachusetts Avenue \\ Cambridge, MA 02138 \\ March 2003
}

\begin{abstract}
Prepared for the 2nd ECB Central Banking Conference. We thank Franklin Allen, Philip Hartmann, Rafael Repullo and Martin Hellwig for useful comments and Fang Yu for his help in collecting the data, the Center for Research in Security Prices and the Stigler Center at the University of Chicago for financial support. The views expressed herein are those of the authors and not necessarily those of the National Bureau of Economic Research.
\end{abstract}

(C)2003 by Raghuram Rajan and Luigi Zingales. All rights reserved. Short sections of text not to exceed two paragraphs, may be quoted without explicit permission provided that full credit including Cnotice, is given to the source. 
Banks and Markets: The Changing Character of European Finance

Raghuram Rajan and Luigi Zingales

NBER Working Paper No. 9595

March 2003

JEL No. G0, G2

\begin{abstract}
$\underline{\text { ABSTRACT }}$
In the last two decades the European financial markets have become more market oriented. We analyze the economic and political forces that have triggered these changes as well as their likely welfare implications. We also try to assess whether this trend will continue. Based on our analysis, we conjecture that even if Europe might benefit from a continuation of the trend, in the near future political support for it is likely to become much weaker. Furthermore, without serious reforms, the trend is likely to benefit Southern Europe less than Northern Europe.
\end{abstract}

Luigi Zingales

University of Chicago, GSB

1101 E. 58th Street

Chicago, IL 60637

and NBER

luigi.zingales@gsb.uchicago.edu

Raghuram G. Rajan

University of Chicago, GSB

1101 E. 58th Street

Chicago, IL 60637

and NBER

raghuram.rajan@gsb.uchicago.edu 
In the last two decades Europe has experienced a dramatic expansion of financial markets, especially of arm's length financial markets. But what are the underlying causes of these changes? Are these causes likely to subside in the next few years? Most importantly, will additional movements in this direction be beneficial to the economies of all the E.U. countries? These are the issues we address in this paper.

We start with a theoretical analysis of the costs and benefits of two polar forms of financing: relationship-based, more prevalent in Europe at the beginning of the decade, and arm's-length, more prevalent in the United States, but increasingly more widespread in Europe during the last decade. Not surprisingly, the analysis suggests that both systems have their costs and benefits. Relationship-based systems perform better when markets and firms are smaller, when legal protection is weaker, when there is little transparency, and when innovation is mostly incremental, rather than revolutionary. By contrast, arm's-length financing delivers superior results when markets and firms are bigger, when firms are more formally organized, when there is better legal enforcement and transparency, and when innovation tends to be more revolutionary. A relationship-based system can provide better forms of insurance, but it does that at the cost of reducing access to financing and curtailing future opportunities. It also relies heavily on implicit or explicit government guarantees. Finally, a relationship-based system facilitates Government intervention, making it both less costly and less transparent. Which system is preferable, though, depends crucially on the environment.

During the last decade, two forces have supported the expansion of arm's length financing in Europe: the process of integration, both monetary integration at the European level and financial integration at the worldwide level, and the revolutionary nature of innovation. Financial systems do not, however, emerge simply as a result of their superiority in a particular environment. The power of vested interest distorts the process of evolution. 
To better understand where the European financial systems are coming from and where they are going, we undertake a historical analysis of European financial development using the lens of political economy. The comparison with the United States is particularly illuminating. Before World War I, European financial systems were more developed than the United States' (Rajan and Zingales, 2003 a). It is only in the 1920s and even more so after the Depression that the U.S. financial system took off (in relative terms) and assumed the form it has today. The cause of this different evolution has to be found in the different initial conditions of the two systems, which affected their responses to the Great Depression.

The U.S. financial system on the eve of World War I was primarily a much fragmented banking system. As Roe (1994) argues, this fragmentation has historically been the result of a populist fear of large financial institutions. In part, this fear was motivated by political rivalry between states and the fear that, if unchecked, New York would control the rest of the country through its strong banks. But this was not the only reason. In Illinois, Chicago banks were prevented from opening branches in the Southern part of the state, to force the reinvestment of farmers' savings in the local market. In Europe the situation was quite different. Before WWI, large national banks were much more central in the allocation of finance.

The concentration of the banking system affected the response to the Great Depression. In Europe the dominance of a few large banks facilitated the formation of a political coalition between more interventionist governments and the banking system. As a result, not only was the legal infrastructure needed to support arm's length markets not fully fleshed out (if not actively suppressed), but also the regulatory framework tilted towards large banks. A similar process occurred in Japan. Thus, neither the European bank-centered system nor the American marketbased one is the natural outcome of market forces. They are both the result of political choices.

In Europe, the nexus between interventionist governments and bank-based systems continued well after World War II, facilitated in large measure by the Bretton Woods System. Because it tolerated restrictions on free capital movements, the Bretton Woods System created 
ample scope for national monetary policies. This independence allowed national governments to interfere and collude with the banking system, generally preventing the development of arm'slength markets. As we describe in Rajan and Zingales (2003 b), the collapse of the Bretton Woods System and the progressive integration of national financial markets, weakened the political opposition to financial markets, leading to their expansion throughout the world, but especially in Europe.

This analysis suggests an alternative reason why the process of monetary and financial integration favored the development of arm's-length markets. Integration opened up domestic intermediaries to foreign competition, which, being foreign, could not be easily controlled through the political process. Thus, external competition limited the ability of incumbents to hamper the development of arm's-length markets. Now that the goal to remove internal barriers is by and large accomplished, however, and that the political objective is to build a common European policy, the effect can be the opposite. The more political powers are transferred to a central authority, the more this central authority can exploit its monopoly power to interfere with market development. Thus, the pro-market bias that has characterized the European Union policy up to now (with notable exception such as agricultural policy), runs the risk of being reversed in the future.

Even if the trend towards markets were to continue, however, its effect would not be all necessarily positive. Arm's length markets need a sound legal, regulatory, and monitoring infrastructure to work properly. The degree to which this infrastructure is in place differs greatly within Europe, with Southern Europe lagging much behind. At the same time, the ability of a country's economy to take advantage of arm's length markets also depends upon its industrial structure. Large, formally organized companies have the necessary scale to generate the information needed by the system at a low cost and to take full advantage of the economies of scale present in arm's length markets. Small businesses are likely to be relatively worse off as a result of this movement toward markets, the more so, the more inadequate the local infrastructure 
is. Since firms tend to be smaller in Southern Europe, this part of the Union might suffer, with neither the benefits of the market nor the certainties of the uncompetitive relationship system, unless it undertakes serious structural reforms.

The rest of the paper is organized as follows. In section 1 we review the changes that have taken place in European financial markets in the last 20 years. In section 2, we describe a theoretical framework to analyze the trade off between relationship-based financing and arm's

length financing. In section 3, we discuss the political conditions for the development of finance, especially for the development of arm's length finance. In section 4, we apply this framework to interpret the recent history of European financial markets and draw inferences about its future. Conclusions follow.

\section{The Financial Revolution in Europe}

As we have discussed elsewhere (Rajan and Zingales 2001a, Rajan and Zingales 2003b) the last twenty years have witnessed dramatic development of financial markets in the United States and throughout the world. Here we want to discuss specifically the changes that occurred in Europe. It is useful, however, to begin with a quick overview of the state of affairs in Europe circa 1980.

\section{1 European Financial Systems circa 1980}

By the early 1980s, Continental Europe was still largely a relationship-based system while the United States and the United Kingdom had become market based financial systems. Crudely put, in the former countries, capital essentially circulated within a set of related firms and institutions, while in the latter countries firms often have to raise money from, and return money to, arm's length parties (see Hellwig (2000) for an excellent description): Hence the terms "relationship" finance and "arm's length" finance. Other terms have been used to describe these different systems: Rhenish Capitalism versus Anglo-American Capitalism or Bank based systems versus Market based systems. To get a sense of the differences, let's compare some rough 
indicators of financial development between Continental Europe and arm's length financial systems, such as the United States and the United Kingdom.

In Table 1, we report these figures for 1980. Not surprisingly, bank deposits were more important in Continental Europe than in the Anglo-American economies. What is remarkable is the difference. Bank deposits relative to GDP were 60 percent larger in Continental Europe than in the United States and the United Kingdom. Bank credit to GDP was nearly twice the level in Continental Europe as a proportion of GDP as that in the U.S. and U.K. The reverse was true for the importance of the stock market. In Continental Europe its weight (relative to GDP) was one fifth of that of the United States and the United Kingdom. In these two countries the amount of equity issued (normalized by Gross Fixed Capital) was twice as large as the amount raised in Continental Europe. While the number of publicly traded companies per million of population was similar, once we remove the unrepresentative outlier of Luxembourg, Continental Europe again has few listed firms.

Since these indicators are very rough, they tend to underestimate the true differences in the development of arm's length markets between the two groups of countries. For example, while in 1980 the United States had several active derivatives exchanges, in Europe only London had an active exchange while Amsterdam had just opened one.

These macro differences also translated into micro differences in the way firms financed themselves. While large publicly traded companies did not differ much in the capital structure (Rajan and Zingales, 1995), small firms did. Consider, for example, the prototypes of the two systems: Germany and the United States. In 1994, only 16 percent of borrowing by firms in the United States was from banks, while 49 percent was through the issue of securities (like bonds and commercial paper). ${ }^{1}$ Unlike bank loans, securities are easily traded, and are held by investors who typically do not want to have more than an arm's length relationship with the issuing firm. By contrast, 80 percent of corporate borrowing in Germany was from banks and only 10 percent 
from securities markets. Banks, by the nature of their large illiquid holdings, tend to have much closer, and longer term ties with firms.

There were substantial differences on the equity side too. Between 1991 and 1995, U.S. corporations annually issued equity amounting to 1.2 percent of GDP. By contrast, German corporations issued equity amounting only to 0.04 percent of GDP. Most telling, there were 3.11 initial public offerings per million U.S. citizens in 1995. The comparable number per million German citizens was only 0.08 (La Porta et al., 1997).

Even the outstanding equity was held very differently. In 1994, individuals held about half the outstanding shares of U.S. corporations. Other non-financial corporations held only 14 percent of each other's shares and banks held virtually zero. In Germany, individuals held only 17 percent, while banks held 10 percent (and also cast the vote for a substantial fraction of the shares held by individuals). Other non-financial corporations held an astounding 42 percent of the shares. Thus other firms and banks owned (and still do) a majority stake in large German firms. Because large institutions rather than individuals own shares in Germany, ownership is much more concentrated. The top 5 shareholders in Germany own approximately 42 percent of shares in the average large corporation, while the number in the United States was only 25 percent.

The large shareholders in Germany tend to be much more protective of the management along some dimensions. Depending on how one counts, there were only 4 hostile takeovers (where the firm taking over does so without the support of the target firm's management) of German firms in the second half of the twentieth century (Franks and Mayer, 1998). The reaction to German steel company, Krupp's, proposed hostile takeover bid for Thyssen (also German, also in steel) in March 1997 perhaps explains why. Thyssen immediately lashed out at Krupp's "Wild West" tactics (in other words, American-style arm's length capitalism rather than the more traditional way of backroom consensus). Krupp's Chairman came under vociferous attack, and had to defend himself, among other things, from a volley of rotten eggs thrown by irate Thyssen

\footnotetext{
${ }^{1}$ These figures and the ones that follow (unless otherwise stated) are from Stephen Prowse (1996).
} 
workers. Politicians right up to Chancellor Kohl became involved, and pressure was put on Krupp's bankers (who also had seats on Thyssen's board) to persuade Krupp to be more conciliatory. While a consensus was eventually reached, and the two firms merged with both managements sharing power, the process was much more highly politically charged and protective of the status quo than would have been the case in the United States.

In sum, in every respect Continental Europe had a financial system more based on banks and institutional relationships than the United States and the United Kingdom.

\subsection{Evolution in the last two decades}

As we report in Table 2, the last two decades have witnessed an expansion of markets everywhere. This is not simply due to an explosion in valuations associated to what is now currently called the "internet bubble". Even in the already market-oriented United States the ratio of stock market capitalization to GDP has increased more than three times as has the amount of investment financed with equity issues. The growth in markets has been even more pronounced in Continental Europe. In the two decades since 1980, the stock market capitalization to GDP ratio went up more than thirteen times while the proportion of investments financed through equity issues went up sixteen times. Though this did not completely eliminate the gap with the Anglo-American economies, it clearly reduced it. In 1980 the stock market capitalization of Anglo-American economies was five times as large as that of Continental European countries, in 2000 it was only sixty percent higher. Many countries in Continental Europe now have a large number of listed firms. Interestingly, while the proportion of bank credit in the United Kingdom has grown substantially and resembles that in Continental Europe, the United States still has relatively small amounts of commercial bank intermediation.

Many Continental European countries have introduced new equity markets - such as the Neuer Markt in Germany -- where disclosure requirements are substantially higher than what has been followed in the past in those countries. The advent of these new markets affected the volume of venture capital financing, which went up substantially (Kukies (2001), Bottazzi and Da Rin 
(2002)). This is not just the effect of the creation of a new market, since countries that introduced new markets with equal or lower disclosure than the established exchange did not experience such an increase (Kukies (2001)). Unfortunately, many of these markets turned out to be shortlived. Following the internet crash and several scandals, for example, the Deutsche Bourse has recently announce it will close the Neuer Markt. ${ }^{2}$ Nevertheless, their creation signified a remarkable change in the European equity culture. Whether this change will survive the stock market downturn, it remains to be seen.

The1990s have also witnessed the explosions of financial derivatives in Europe. At the end of the 1980s and beginning of the 1990s all the European countries introduced a derivatives exchange and the amount of derivatives outstanding went from $\$ 2.7$ billion in 1986 to $\$ 2.4$ trillion in 2001. More noticeably, the share of trading of derivatives on European exchanges increased remarkable. As figure 1 shows, the fraction of worldwide open interest contracts traded on European derivatives exchanges went from less than $1 \%$ to more than $25 \%$ in 15 years. Interestingly, European markets have a smaller and decreasing share in currency derivatives (probably as a result of the euro), but a larger and increasing share in equity index derivatives (Figure 2).

The increased role of markets can also be appreciated by looking at growing importance of corporate debt issues. Domestic corporate debt grew from 13\% of GDP to 17\% of GDP (Table 4), and international corporate debt grew from $2.4 \%$ of GDP to $6 \%$ of GDP.

Most interestingly, markets are slowly replacing banks in many of the traditional roles performed by the latter. The best example is securitization, where traditional loan and mortgages are packaged together and sold as securities. As Figure 3 shows, in the last four years alone, the volume of asset and mortgage backed securities having underlying collateral from Europe placed in the Euromarket, or in European domestic markets, increased four times.

\footnotetext{
${ }^{2}$ The Neue Markt will be substituted by a "premium segment", which has not the same characteristics of the Neue Markt.
} 
There are also many qualitative signs of the changed attitude toward financial markets. Traditionally, the Continental European attitude toward shareholders was epitomized by Carl Furstenberg, a German banker ${ }^{3}$

"Shareholders are stupid and impertinent - stupid because they give their money to somebody else without any effective control over what this person is doing with it, and impertinent because they ask for a dividend as a reward for their stupidity."

This attitude is very much changed. In recent years, German companies have been advertising their adherence to the principle of shareholder value maximization in the financial press. ${ }^{4}$ This is not simple cheap talk. Disclosure standards have improved throughout the Continent as have laws to protect minority shareholders. For example, in Table 6, we report the year of introduction of a law to prosecute insider trading and the year this law was applied for the first time. Before 1980 no EU country, except France and Sweden, had an anti insider trading law. And while in Sweden the law was introduced in 1971 the fist insider trading case was not brought until 1990. This latter date is more important than the former, since Bhattacharya and Daouk (2002) show that investors' required rate of return falls not when a law is passed, but when it starts to be enforced. By the end of the century, all EU members had an anti-insider trading law and most of them had also started to enforce it.

In sum, although relationship-based finance still remains pervasive in Europe, the last twenty years have seen a clear expansion of the sphere of arm's length markets. What is less clear, however, is the origin of this trend. Is this simply a reflection of an international movement toward arm's length financing, may be due to the market euphoria of the end of the century? Or is it an effect of the progressive integration of Europe culminating with the introduction of the Euro? Is this trend likely to continue in the future? And is it necessarily positive for all the members of the European Union? What can be done to alleviate/ ameliorate the effects of this trend? In order to answer all these questions we need to take a step back and review what are the

\footnotetext{
${ }^{3}$ Cited by Martin Hellwig (2000) p109.

${ }^{4}$ See e.g. Veba's advertising in the Wall Street Journal.
} 
conceptual differences between these two types of financing and what are their pluses and minuses.

\section{Relationship-based vs. arm's-length financing}

"Relationship-based" and "arm's-length" refer to two polar form of financing. As Rajan and Zingales (1998a) argue, relationship-based financing ensures a return to the financier by granting her some form of power over the firm being financed. The simplest form of power is when the financier has (implicit or explicit) ownership of the firm. The financier can also serve as the sole or main lender, supplier, or customer. In all of these forms, the financier typically attempts to secure her return on investment by retaining some kind of monopoly over the firm she finances. As with every monopoly, this requires some barriers to entry. These barriers may be due to regulation, or to a lack of transparency -- or "opacity" -- of the system, which substantially raises the costs of entry to potential competitors. In arm's-length financing, instead, the financier is mainly or solely protected by explicit contracts.

Relationship financing is largely self-governing; parties intent on maintaining their "reputations" honor the spirit of the agreement (often in the absence of any written contract) in order to ensure a steady flow of future business within the same network of firms. By contrast, the prompt and unbiased enforcement of contracts by courts is a pre-condition for the viability of a market-based system. Moreover, since contracts are typically hard to write with the wealth of detail necessary to fully govern transactions, it is important that the law offer a helping hand.

Let us consider the example of a transaction -- the extension of credit -- in each of the two systems. These are, no doubt, caricatures, but they will serve the purpose if they highlight the essential forces in each system. In a relationship-based system, a bank will have close ties with a potential borrowing firm, perhaps because of frequent past contacts or because of ownership links. In assessing the borrowing needs of the firm and its ability to pay interest and principal, the bank will consider not only the firm's current debt-servicing capability, but also its long-term 
ability to repay, and the various non-contractual levers the bank can push to extract repayment. The interest rate charged will be repeatedly negotiated over time, and may not have a direct relationship to the intrinsic risk of the project.

In an arm's-length system, by contrast, the firm will be able to tap a wider circle of potential lenders because there will be more widespread financial information about it. The loan will be contracted for a specific period, and the interest rate will be a competitive one that will compensate the lender for time and the risk of that particular loan.

Limitations on competition in a relationship-based system do not just give the financier power, but also strengthen his incentive to cooperate with the borrower. Studies of Japanese keiretsus show that the main banks went out of their way to help financially distressed borrowers. For example, Sumitomo Bank not only effectively guaranteed Mazda's debts when it got into trouble after the first oil shock, but also orchestrated a rescue, in part by exhorting employees within its keiretsu to buy Mazda cars (Hoshi, et al., 1990b). Sumitomo's incentive to help would have been considerably weaker if Mazda had had the option of giving the lion's share of its business, once it emerged from distress, to some other bank. The effective limitations on outside competition imposed by the keiretsu system enable lenders to "internalize" a greater share of the benefits accruing to the borrowers than is possible in an arm's-length, competitive banking environment.

The absence of competition and disclosure in a relationship-based system imply that there are really no price signals to guide decisions. Unlike an arm's-length system, where a number of competitive lenders can give a borrowing firm independent assessments of the costs of undertaking a project, the cost a borrower faces in the relationship-based system is simply what the relationship lender and the borrower negotiate. Since there can be substantial value created in the relationship, and the negotiation and allocation of this surplus is a function of each party's power, the effective cost of financing can deviate substantially from the true risk-adjusted cost. 


\subsection{Theoretical differences between the two types of systems}

While there is clearly an overlap between our classification and the classification of systems as bank-oriented or market oriented (or more recently, Rhenish Capitalism vs Anglo Saxon Capitalism), the two are not the same. Relationship-based financing is more typical of, but not unique to, banks. Venture capital financing is very much relationship-based, even though it is typically not done by banks, and is found largely in market-based economies. Similarly, multiple banking relationships tend to reduce the power of each individual bank, leading to a system that has many aspects of an arm's length one. As a result, we find it more fruitful to study the welfare consequences of the pure stereotypes and only later analyze how these affect the functioning of real-world financial systems. For an excellent welfare comparison of intermediaries versus markets see Allen and Gale (1995).

\section{1) Response to price signals}

By its very nature, a relationship-based system does not pay much attention to market or price signals. In such a system financing cannot take place in the presence of intense competition. Hence, it will only occur when competition is somehow restricted, and hence when prices tend to be not very informative. But this indifference to price signals also becomes selffulfilling. If investment decisions are not driven by prices, then prices become less effective in providing economic directions because they reflect less information.

Evidence of this unwillingness to respond to market signals is provided by Hoshi, Kashyap, and Scharfstein (1991). The study looked at a sample of Japanese firms in the late 1970's to mid-1980's that had close ties to banks and compared their investment behavior with a sample that had no such ties. The investments of firms that had no bank ties were very sensitive to the cash flow the firms generated from operations; when operating cash flows decreased sharply, so did investment spending, and vice versa. By contrast, the investments of firms with strong ties to the banks were significantly less sensitive to the firms' operating cash flow.

One possible interpretation of these findings is that banking relationships make it easier 
for firms to obtain external funding for value-adding investments, thus making them less dependent on their own cash flows. But recent events in Japan suggest a different explanation. More often than not, the companies' continuous access to bank funding on favorable terms allowed them to ignore the signal sent by their poor cash flows, and to continue investing. By continuing to invest in these circumstances, such firms may well have been destroying long-term value rather than increasing or preserving it. Even if the banks were failing to provide the managers of these firms with the right signals, it appears that the stock market was attempting to do so. For, as the study also reports, the firms with banking relationships in their sample had lower "Tobin's q" (or market-to-replacement cost) ratios than firms without bank ties. And, to the extent that Tobin's q is a reliable proxy for a firm's investment opportunities, the stock market was expressing skepticism about the likely payoff from such investments.

Peek and Rosengren (1998) provide additional evidence that relationships can distort the allocation of funds. In the early 1990's, Japanese banks increased their lending to the U.S. commercial real estate market. At their peak in 1992, the U.S. subsidiaries of Japanese banks accounted for one-fifth of all commercial real estate loans held in the U.S. banking sector. Then, in response to a severe decline in real estate prices in Japan, the Japanese banks cut back their lending in the U.S. even as U.S. prices were rising (and lending by non-Japanese banks increasing), while at the same time expanding their lending in the domestic Japanese market where prices were plummeting. Thus, rather than cutting their losses in Japan -- or at least not abandoning their profitable opportunities in the U.S. -- Japanese banks poured more money into their unprofitable Japanese relationships.

This is not to say that the arm's-length system is perfect in the allocation of resources. Because outsiders have little power, management can indulge itself far more in empire-building without triggering an intervention by outsiders. This problem has been labeled the "agency costs of free cash flows" by Michael Jensen (1986). The arm's-length system, however, can use 
takeovers to rectify this problem when it gets excessive. ${ }^{5}$ By contrast, the problem of misallocation of resources due to the lack of price signals in the relationship-based system is more severe, because it lacks a self-activating mechanism to correct it. In fact, even if price signals were accurate, the power structures in the relationship-based system may not allow movement in a direction indicated by the prices.

In market-based economies, however, there is a virtuous circle at work: In the process of relying on prices for guidance, the arm's-length transactions that predominate in these economies also have the beneficial effect of making prices more informative. Thus, the more transactions that come into the market, the more likely it is that decisions made on the basis of price are likely to be the right ones.

In sum, one downside of a relationship-based system is that price signals are obscured.

The consequence could be a widespread and costly misallocation of resources.

\section{2) Sensitivity to bubbles}

Recent experience might suggest that paying too close attention to market prices may also be harmful, especially if those prices seemingly depart from fundamentals. The euphoria that gripped investors in the United States in recent years has, according to some, led to egregious mispricing (see, for example, Lamont and Thaler (2001)), which in turn has led to what in hindsight is obviously inappropriate real investment. Clearly, the benefit of paying attention to stock prices relative to the benefit of ignoring them depends on their signal-to-noise ratio. We do not have any studies that have attempted to quantify this.

What we do know is that the signal to noise ratio in stock prices varies widely across countries. In recent work, Morck et al. (2000) decompose stock price volatility into market-wide and firm-specific elements. While market-wide movements are not necessarily bubbles, this decomposition gives us a sense of how much firm-specific information is contained in stock

\footnotetext{
5 If anything, managerial empire building is less severe in a relationship-based system, precisely because financiers have the power to intervene extensively and absorb free cash flows from successful firms.
} 
prices (and to the extent that market moving events are publicly observable, this decomposition offers us a measure of how much additional information stock prices provide about individual firms). The proportion varies widely across countries. In a developed market like the United States market-wide movements explain only 3 percent of the daily variation of individual stocks, while in developing countries such as Taiwan and Poland they explain far more (approximately 40 percent and 60 percent respectively). Thus, markets differ in the amount of company-specific information that is incorporated into stock prices and more developed markets produce more of it. Thus markets are more likely to be useful in guiding investment in developed countries, and there is some evidence of this (see Wurgler (2000)).

Even though they focus less on stock prices, relationship-based systems are not immune to bubbles either. In fact, the Japanese economy, traditionally a relationship-based system, has been deeply affected by the bubble in land prices that developed over the 1980s. Interestingly, the transmission channel has been different. Japanese banks did not react to stock prices directly, but to increases in the collateral value of land (see Kashyap et al. (1990)). The bursting of the bubble in land prices left the Japanese economy with a huge debt overhang, which has still not been worked off.

In sum, relationship-based financing and arm's-length financing are sensitive to different type of euphoria. The former is more sensitive to institutional euphoria, the latter to individual euphoria. Which form of euphoria is more frequent, and which one has the worse consequences is a topic that awaits future research.

\section{3) Market power}

Another consequence of prices being obscured in a relationship-based system is that the financier's information is largely private especially when the projects being financed consist of intangible assets such as intellectual property. As a result, in a relationship-based system the initial financier tends to appropriate a greater share of the return to new technologies. On the one hand, this depresses the incentives to form new start-up ventures, making entrepreneurship in 
high tech industries a rare phenomenon. On the other hand, it facilitates the exploitation of new technologies by existing firms (Hellwig (2000), Rajan and Zingales (2001a and c)), increasing their scope (hence the proliferation of conglomerates in relationship based systems). Which system is more effective depends on the type of innovation and on the organizational incentives of existing firms to undertake this innovation, a topic we will return to momentarily.

\section{4) Illiquidity}

Because information is so concentrated in a relationship-based system, financial assets become very illiquid. Since the relationship is specific to the intermediary and borrower, the intermediary becomes indispensable to collecting on loans. Loans will be illiquid in that outsiders will not be able to extract as much repayment if the loan is sold as can the insider institution. Not only does this mean that the intermediating institution has highly illiquid assets, it also means that its cost of capital will be high unless it can somehow commit not to extract rents from its investors (given that its expertise is so critical in collecting on loans, once financed, intermediary managers can demand a high rent for their specialized skills). Financial intermediaries can commit to their investors by raising finance through hard-to-negotiate instruments such as demand deposits (see Diamond and Rajan (2001)). Nevertheless, extensive rigid financing of this kind leaves the economy overexposed to adverse shocks that can take down intermediaries. Intermediary distress is all the more dire in relationship economies because their financial assets are so illiquid and have so limited a market.

\section{5) Risk}

By its very nature, a relationship-based system tends to smooth shocks intertemporally. As we have just discussed, the prospect of future rents induced Sumitomo to intervene and bail out Mazda in the early 1970s. By contrast, in an arm's-length system, competition eliminates future rents, destroying any incentive to pay for the cost of a bailout. More importantly, in an arm'slength system such intervention cannot even be insured contractually at a reasonable cost. Unconditional insurance would create the conditions for severe moral hazard, while the right 
contingent insurance might be too complex to be written into a contract. Hence, relationshipbased systems smooth better individual shocks than arm's-length systems.

The opposite is true for systemic shocks. Because of lack of transparency and disclosure in relationship-based systems intermediaries finance assets that only they understand (Diamond and Rajan (2001a, 2001b)). Not to absorb a massive amount of rents, they have to credibly commit to pay out collections to depositors. This requires them to issue hard claims; the hardest being demandable claims subject to runs. Thus in the natural course of financing illiquid relationship-based assets, financial intermediaries have to take on financial risk. To reduce this risk, the government has to promise intermediaries contingent capital, which in turn causes them to bet on the same risks such as real estate or emerging market lending, knowing full well that they will be rescued if only they sink together.

Contrast this with the arm's-length system where the accent is on providing small investors the confidence to invest directly in firms. The arm's length system permits more flexibility in explicit contracts, which allows the system to absorb adverse shocks. Moreover, the healthy can be distinguished from the terminally ill after a shock and can be dealt with differently - not everyone has to sink or swim together as in the relationship system. Finally, unaffected outsiders have the ability to invest and revive the system, as they obtain confidence from the very same channels that inspire confidence in small investors. Thus, in general, arm's length systems can deal with system wide adverse shocks better.

All this suggests that if an adverse shock affects an economy unevenly, the arm's length system will be better able to identify and isolate the truly distressed and prevent them from taking the system down. In a relationship system, the pain is likely to be widely shared and in ways that make more sense politically than economically. This kind of system-wide insurance can be beneficial in smoothing temporary economic shocks (Diamond and Dybvig (1983), Allen and Gale (1997 and 2000)), but prevents necessary adjustment when shocks reflect the necessity for structural change. 


\section{6) The Kinds of Assets Financed by Each System}

Taken together, the above discussion suggests that pure relationship-based systems tend to have a comparative advantage in financing physical-asset-intensive industries rather than high technology research and development based industries. For one, physical-asset-intensive industries are typically more traditional and well understood. As a result, the absence of market signals about their profitability is less likely to be a problem in making investment decisions.

Second, because they are well understood, it is unlikely that a large amount of rents will accrue to the financing intermediary. Moreover, the borrower has the collateral to entice fresh lenders if the existing ones prove overly demanding. Finally, since loans are well collateralized by physical assets, they are liquid, so the concentration of information in the system will not be a barrier to financing these assets.

Conversely, arm's length systems will have a comparative advantage financing industries with intangible assets; hence Carlin and Mayer's (1998) finding that equity- and skill-based industries tend to do more research and development in economies with better developed accounting standards.

An intriguing recent study fortifies our view that relationship-based systems are more capable of financing projects where the ratio of tangible to intangible assets is large. Houston and James (1995) study the financing arrangements of 250 public firms in the United States. They find that firms with relationships to single banks tend to use less bank debt in proportion to total debt as their market-to-book ratio (a measure of the ratio of intangible to tangible assets) increases. By contrast, when firms have relationships with multiple banks, the ones with higher market-to-book ratios tend to use more bank debt in proportion to total debt. This suggests that firms tend to avoid becoming dependent on a single bank when they have high market to book ratios, perhaps because they fear the bank may have too much power to extract rents and direct strategies, or because the bank itself will find the asset too illiquid.

\section{7) The types of firms financed in each system}


Not all firms can take equal advantage of the two systems. Financing in an arm's-length system has higher fixed costs, but enjoys better economy of scale. To enjoy the benefits of disseminating information, a company has first to produce such information in a credible way. This entails significant fixed costs. The cost of setting up a computerized inventory system, which automatically records cost of inputs and sales, does not differ greatly for a "mom and pop" store than for a large retail chain. Once this system is in place, the cost of producing information that can be easily verified by the accountants, and thus by the market, is small. Hence, the relative cost of producing information is lower for larger firms.

Similarly, different organizational structures have a different propensity to generate information. As Novaes and Zingales (1998) show, multi-layer hierarchies tend to produce more verifiable information than two-layers' ones to reduce the rent middle managers can appropriate. ${ }^{6}$ This information, generated for internal purposes, can easily be used for external purposes at no additional costs. Similarly, because franchisees have to generate more information for the purposes of reporting to the franchiser, they are more able to raise external finance (Petersen and Rajan (2003)) from distant, arm's length investors.

Thus, large multi-layer organizations can benefit from arm's-length markets much more than small owner-operated firms. Not surprisingly, the United Kingdom, which has more developed arm's-length markets, has larger firms than any other European country (Kumar et al, 2000) and there is a positive correlation between development of arm's-length financial markets and the separation of ownership and control (La Porta et al., 1999).

\section{8) Financing of Innovation}

An arm's-length system, where there is more public information, gives new firms, attempting new technologies, a better chance of obtaining financing. The reason is that there are many investors from a variety of backgrounds, each of whom has the basic information to assess 
a new technology. While each investor may be biased, and each investor may receive only part of the information that is collectively known, each investor investigates the firm's prospects independently. Thus the firm gets a number of chances to attempt to convince investors of the merits of its technology. If the technology is sufficiently new, it may need all those chances to obtain financing somewhere. ${ }^{7}$

The relationship-based system works in a very different way. Given the paucity of public information and the limited access in a relationship-based system, the firm has, at best, one or two well-informed financiers who can make an assessment. Since information in such a system is generated through contacts rather than posted publicly, those financiers are likely to talk to each other. So while collectively they may have more information, and make a better decision about whether to finance the new technology, the firm will not get much more than a single chance to make its case.

If the technology is a minor modification of tried and tested technologies, the payoffs from funding eventually successful technologies is likely to be small, at least relative to the costs of funding failures. A relationship-based system is likely to be better here because it has the ability to probe deeper and screen out most of the likely failures. The system's conservatism, as reflected in the extreme scrutiny that innovations are subject to, could lead to the rejection of some worthwhile innovations. But this is not very costly relative to the gains from not funding failures. In normal times where change is incremental (and innovations are as likely from within the establishment as from outside), the relationship system works well.

If, however, we are in a period of extraordinary change, where revolutionary innovations may enable firms to create entirely new profitable markets, the free access market-based arm's length system is better in making sure that most of these get financed, even though many failures

\footnotetext{
${ }^{6}$ In fact, in their model multilayer hierarchies produce an excessive amount of verifiable information with respect to what would be optimal in the absence of agency problems. They do not consider, however, the positive effect this information might have on the firm's ability to finance its projects.
} 
will also be financed. The value from the successes far outweighs the costs of failures at such times so using independent but informed evaluations works better in financing innovation.

One can even extend the parallel to venture capital, the latter being an institution that seems to emerge only in free access financial systems with high disclosure. Venture capitalists invest only a little at a time. They continue only projects that look as if they will be great successes, but quickly cut short those that look as if they will be dogs. Thus they reap a bonanza from the successful projects, while losing little from those that fail. This sort of return profile makes them willing to experiment. As a result, entrepreneurs need not be dejected by a single rejection by a venture capitalist since there may always be some other venture capitalist who sees things more their way. Successful entrepreneurs in market-based financial systems often have tales of how they peddled their projects from door to door until they eventually found a venture capitalist willing to put pen to checkbook.

Venture capitalists themselves, let alone such tales, are rare in relationship-based economies. They are rare because venture capitalists need a reliable system of disclosure, not just because they fund young companies, but also because they get their reward only when they grow these firms to the point that they can be sold on the public equity markets. And for the public investor to pay an adequate price for the shares that are sold, they have to be confident of what is truly going on inside the firms. Reliable disclosure makes such confidence possible (Black and Gilson (1998) and Kukies (2001)).

Even if financing is available, however, it is not safe to assume, as we have done, that established firms will want to undertake projects that lead to extraordinary change. Technological change can render obsolete the expertise of those who run the firm. ${ }^{8}$ Young firms are therefore

\footnotetext{
${ }^{7}$ This argument is based on work by Sah and Stiglitz, AER, 1986. See also Allen (1993) in the Mayer and Vives volume for a different application of the Sah and Stiglitz point.

${ }^{8}$ Even though IBM's personal computer set the industry standard, it was Intel and Microsoft that constantly pushed the technology forward, and reaped much of the gains. Part of the reason why IBM did not exploit the possibilities in the personal computer better is because IBM's agenda was set by top management who had cut their teeth on mainframes. In an attempt to avoid cannibalizing mainframes, they
} 
special when there is a potential for extraordinary change because they have no vested interests in the status quo. More disclosure and transparency, and the associated free access to finance, helps the emergence of new firms. In stark contrast, the relationship system is particularly bad at giving newcomers a chance. Newcomers invariably have to become part of the system before they can get finance, because no one can trust their accounts, or will give them access before they pay their dues. No wonder the average age of corporations making initial public offerings on the Deutsche Bourse between 1960 and 1990 was 57 years, an age which would be deemed ancient for American corporations (Rydqvist and Hogholm, 1995). Within the United States itself, the deregulation of banking in the 1980s led to a substantial increase in competition in the financial sector in states that deregulated. This was tantamount to a shift from an uncompetitive, relationship system before deregulation to more competitive, arm's length financing afterwards. Not surprisingly, the rate of creation of new enterprises jumped significantly after deregulation (Black and Strahan, 2002).

Relationship finance therefore has at least two strikes against it at times of great change. First, the way the system scrutinizes new ventures makes it more likely that more out-of-theordinary new opportunities will be left without finance than in the arm's length system -- decision by consensus is inherently conservative. Second, the opaque nature of the system makes it discriminate against outsiders, especially newcomers. Thus, those who have the greatest incentive to force change have the least resources to do so. Since the players in the system lack both the mindset and the incentive to innovate, relationship finance is a serious drag in times of great change.

\footnotetext{
placed constraints on the development of the personal computer, which undermined their leadership position in the PC industry. For example, "IBM crippled its own Displaywrite word-processing package by limiting its ability to handle electronic mail, which became a hugely popular application. This was back in the days when IBM still thought of typing as something to be done on a mainframe or minicomputer, and the mainframe people wanted to protect their mainframe-based email system, called PROFS, by keeping email off PCs. In addition, mainframe executives argued that the hundreds of thousands of secretaries who had gotten used to PROFS and the mainframe version of Displaywrite did'nt really want any new features."
} 
But there is a third strike also. Relationship systems tend to protect mature incumbent firms that get into trouble. In normal times, this lends stability to the system. In times of extraordinary change, this can keep resources far too long in unproductive uses. There is no better example of the ambivalent nature of the protection afforded by financiers to firms than the abovementioned rescue of Mazda by Sumitomo bank in the 1970s.

Was the rescue worth it? The answer is not obvious. In the short run, Mazda recovered. It may, however, have been a mistake to ignore the signals obtained from Mazda's poor performance. A re-interpretation of the Mazda example is that perhaps Mazda deserved to be taken over by another automobile manufacturer-- after all it was in trouble again in the early 1990s when it had to be rescued by Ford! Maybe it should have been shut down thus reducing the overcapacity the automobile industry has been plagued with in recent years. Who knows whether the net long-run benefits to Mazda from Sumitomo - the guarantees and the credit, less the interest payments, the tied deals, and the long-term submission to Sumitomo's direction - were positive? And even if positive, did this deal make sense for Sumitomo's depositors and equity holders, or for Japan as a whole?

Unfortunately, as we have argued, the relationship system makes it difficult to undertake such a cost-benefit analysis - after all, that is precisely why the system comes into existence. How does one value the loss borne by other members of the keiretsu for being "encouraged" to buy Mazda cars? How big are the profits forgone by Sumitomo for spending so much of its managers' time in rescuing Mazda? It is precisely this opacity that condemns the system to make mistakes. And all the mistakes go in one direction, towards protecting unviable incumbents. The fabled long-term view of the relationship system may, in fact, be very short term.

\section{9) Political Controllability}

There is another obvious, but often ignored, difference between the two systems: the ease with which they allow governments to intervene. A relationship-based system is naturally more prone to government direction because it depends more heavily on the government to maintain 
the restrictions on competition that enable it to work. Furthermore, in an opaque environment financial intermediaries need some government supervision to be perceived as reliable. This supervisory power, however, gives the government a powerful lever it can use to coerce these intermediaries into actions it deems desirable. This exercise of (im)moral suasion is not unique to relationship based systems. The New York Fed's intervention in the rescue of Long Term Capital Management in 1998 suggests arm's length systems are not immune. But the very nature of a relationship-based system makes these interventions easier, less visible, and thus more appealing politically.

The opacity of the relationship-based system makes it easier for the Government to intervene also because hides the real cost of this intervention. In the 1930s, the Japanese Nationalist government used the banking system, which it had previously helped consolidate, to channel more resources to munitions production. Such intervention required neither an explicit bill, nor a visible item in the government budget. As such was much more appealing. There is, thus, a natural symbiosis between interventionist government and relationship-based systems: Relationship-based intermediaries prosper under government-sanctioned protection from competition and interventionist governments enjoy greater flexibility and power in a relationshipbased system.

\subsection{Relative efficiency of the two financing modes in different environments}

Thus far, we have compared the strengths and weaknesses of the two financing modes without considering the environment in which they operate. Clearly, their relative merits may differ with the environment.

Arm's length financing, for instance, relies heavily on legal protection and judicial enforcement, while relationship financing is largely self-enforcing, requiring just the protection of the most basic property rights. Hence, in countries with poor legal protection and judicial enforcement, not only is relationship financing preferable, it is the only option. 
The benefits produced by an arm's length system are greatest when more information is available, when this information is reliable, and when it can be easily diffused. Thus, an economy with larger and more formally organized firms can profit the most from an arm's length system.

The benefits of an arm's length system are also greatest in economies where the information disclosed is reliable. This requires, for instance, that there be no implicit penalty to disclosing this information. Systems where the visibility to the tax authorities changes depending on the amount of information in the public domain do not meet this condition. Similarly, systems where corruption is widespread also fail this condition, because they place the reliable discloser at a competitive disadvantage in paying bribes to the opaque competitor.

Reliable disclosure also requires appropriate penalties for lack of timely disclosure. ${ }^{9}$ Recent scandals in the U.S. show how doubts on the reliability of information can undermine investor's confidence. If this occurs even in the country with the best tradition of pursuing accounting frauds, one can only imagine what happens in the other ones.

Finally, information needs to be transmitted. Petersen and Rajan (2002) show how the diffusion of standardized information and cheap telecommunications has increased the distance between borrower and lender in the United States. Thus, when information can be easily diffused, competition to lend increases, and the benefits of an arm's length system also increase. In this sense, the advent of the Internet is playing a big role in making arm's length financing more attractive.

The benefits of an arm's length system are also linked to the size and diversity of the potential market that can receive the information. In a small homogenous market with a limited number of players, the benefit of competition among lenders is minimal. When the potential financiers are few, they can collude at the expense of entrepreneurs, as venture capital firms

\footnotetext{
${ }^{9}$ Penalties can be excessive so that firms disclose more than socially optimal. For instance, firms may be forced to disclose trade secrets or competitive strategies, which may lead them to underinvest in business innovation. It may also force them to disclose all the information they have without making judgements as to what is important, leading investors to be no wiser.
} 
appear to have done before the expansion of the VC market in the late 1990s. But a limited market size and the lack of industrial diversity also decrease the potential benefits provided by prices. The information conveyed by prices is useful because it may lead to a reallocation of resources. In a small homogenous economy, with limited opportunities for reallocation, the benefit of having this information is also limited and so is the value added of an arm's length system. Hence, the comparative advantage of a relationship system versus arm's length system depends crucially on the size and diversity of the potential market they are facing.

In sum, relationship-based system perform better when markets and firms are smaller, when legal protection is weaker, when there is little transparency, and when innovation is mostly incremental, rather than revolutionary. Thus, relationship-based systems work best in the early stages of industrialization where the industries to be financed are physical asset intensive, where the legal system is ineffective, and where skill-based or idea-based industries are of limited import. They also work best in small, homogenous, closed economies.

By contrast, arm's-length financing deliver superior results when markets and firms are bigger, when firms are more formally organized, in the presence of better legal enforcement and transparency, and when innovation tends to be more revolutionary. Thus, as economies develop and focus more on knowledge-intensive industries as engines for growth, a hybrid is perhaps more effective. There is then the need to improve transparency, judicial efficiency, and mechanisms for speedy resolution of financial distress so that arm's-length markets can function effectively and aid the process of economic growth.

\subsection{Financing Modes and Financial Systems}

Thus far, we have just characterized the two extreme modes of financing. No real world financial system could be classified as purely arm's length or purely relationship based. They all rely on both modes of financing. The difference rests in the relative importance of these modes and how they are combined. U.S. venture capital, for instance, seems to combine the best elements of both financing modes. As in any relationship-based financed, the intense involvement 
of the venture capitalist in the firm (the typical lead venture capitalist visits the entrepreneur once a month on average and spends four to five hours at the facility during each visit (Gorman and Sahlman, 1989)) ensures the financier a monopoly on the firm financed, guaranteeing her both a return on her investment and an incentive in working out any necessary restructuring. But the contractual time limit on the funds raised, the restrictions on the amount of funds invested in each venture, and the availability of a liquid market to unload her investments eliminate any risk of a hold up by the initial financier, typical of relationship-based financed.

By contrast, short-term financing of long-term relationships, as it was the case of EastAsian systems, seems to combine the worst of both modes. From the borrower perspective, the short-term nature of the financing substitutes for the lack of information. But from a welfare perspective, these arrangements are deficient both from the point of view of information aggregation and from the point of view of insurance, since the lack of any monopoly power dissuades the financiers from being involved with the borrower in case any problem arises.

Of course, which type of financing is prevalent and which combination emerges is driven, at least in part, by the surrounding legal and institutional environment. Where information cannot be credible generated and diffused, short-term financing might be the only available alternative.

\subsection{What Recent Corporate Scandals in the United States Suggest about the Relative Desirability of the Two Systems?}

Since the United States are often used as the prototype of an arm's length financial system, the flurry of U.S. corporate scandals can easily be interpreted as evidence against this type of system. This would be a hasten conclusion. While the U.S. financial system is more market-based than that of any other country, it is not purely market based. And while the United States has better disclosure rules than most countries, its rules are far from perfect. In fact, most of the problems that are surfacing now in the United States have to be attributed more to the 
distortions created by relationships in the absence of proper disclosure than to the intrinsic limitations of arm's length systems.

Consider for example the IPO spinning practices under investigation by Spitzer, the New York Attorney General. According to Spitzer, several investment banks used their discretionary power in allocating IPO stocks to secure captive business. CEOs of technology firms were personally awarded hot IPO stocks of other firms underwritten by the investment bank as a way to woo future business. This practice, if ascertained, is the ultimate example of the distortions that arise in an opaque system. It is the lack of mandatory disclosure of IPO allocation practices that gives investment bankers this power. In a transparent market this power will not exist.

Similarly, the failure of Arthur Andersen to uncover the accounting irregularities at Enron is most likely due to the excessively cozy relationship between Enron and its auditors, relationship cemented by millions of consultancy fees. And the ease with which Enron could conceive its accounting practices from the market was made possible by the lax disclosure standards in consolidating subsidiaries' accounts.

In sum, the recent U.S. corporate scandals suggest that even the United States have a long way to go if they want to make their system truly transparent. These scandals do not, however, undermine the arm's length system per se. To the contrary, they show that opaque relationships breed abuses and frauds, not only in East Asia and Russia, but also in the United States. It is not a cultural issue, thus, it is an issue of incentives.

Where recent events may undermine the case in favor of arm's length systems is in the investment distortions produced by the so-called internet bubble. According to preliminary estimates the telecommunications boom and bust may have triggered nearly half a trillion dollars of excess investments (Roberts, 2001). As we already discussed, however, bubbles do not arise just in arm's length systems. After ten years, Japan is still suffering the consequences of its real estate bubble, mostly fueled by its banks' lending practices. Unfortunately, a comparison of the 
magnitude of these distortions and their likelihood in the two types of systems still awaits future research.

\section{The Political Economy of Financial Markets}

Thus far, we have only discussed the relative efficiency of the two systems. But they also have important re-distributional effects and it would be naïve to believe that these play no role in the actual choice of which system prevails. This is especially true because many of the environmental conditions, which determine the relative efficiency of the two systems, such as legal enforcement and mandatory disclosure, are not exogenously given but are the results of political choices. These choices are very much affected by distributional issues.

Hence, to understand the prevalence of different financial systems and their evolution we have to quickly review the political economy of finance.

\subsection{Why finance is not liked}

A large body of literature (for a survey see Levine, 1997 and Rajan and Zingales, 2001b) shows that financial development is beneficial. Then, why anyone would oppose it? The answer has to be found in the distributional effects of increased access to finance and in the relative political power of the groups affected.

As Rajan and Zinagles (2003a and 2003b) argue, financial development could pose a threat to established large industrial firms, a group we will call industrial incumbents. In normal times, these incumbents do not require a developed financial system. They can finance new projects out of earnings - as most established firms do -- without accessing external capital markets. Even when their business does not generate sufficient cash to fund desired investments, they can use the collateral from existing projects and their prior reputation to borrow. Such borrowing does not require much sophistication from the financial system -- even a primitive system will provide funds willingly against collateral. Because of their privileged access to finance in underdeveloped financial systems, incumbents also enjoy a positional rent. Anybody 
else who starts a promising business has to sell it to the incumbents or get them to fund it. Thus, not only do incumbents enjoy some rents in the markets they operate in, but they also end up appropriating most of the returns from new ventures.

All these rents will be impaired by broadening the access to finance. A more efficient financial system facilitates entry, and thus leads to lower profits for incumbent firms. From the perspective of incumbents, the competition-enhancing effects of financial development may offset the other undoubted benefits that financial development brings.

Critical to the above arguments is that financial development aids the entry of new firms, thus enhancing competition. There is some evidence for this. In a comparative study of the textile industry in Mexico and Brazil around the beginning of the twentieth century, Haber (1997) shows that Brazil, following its political revolution, liberalized finance, and saw the textile industry grow faster and become less concentrated than the Mexican textile industry. Porfirio Diaz, the Mexican dictator during this period, was much more a prisoner of incumbent interests. Mexico's financial markets remained underdeveloped during his regime, with the consequence that Mexico's textile industry, while starting out larger and relatively more competitive, had less entry, and ended up smaller and more concentrated than Brazil's. Studies of larger samples of countries support the idea that financial development facilitates entry by newcomers. Rajan and Zingales (1998b) find that the growth in the number of new establishments is significantly higher in industries dependent on external finance when the economy is financially developed. Johnson et al. (2000) find in a study of trade credit in transitional economies that an important consequence of an effective legal system in a country is that a firm offers more trade credit to new trading partners.

Financial underdevelopment is not the only barrier to entry. Incumbents with political influence could restrict or prevent entry into their industry directly through some kind of licensing scheme. In Rajan and Zingales (2003a) we discuss why, in spite of the existence of other, more direct instruments, to prevent entry, financial repressions might still be used. 


\subsection{Relationship-based versus arm's length finance}

While incumbents might dislike finance in general, they dislike arm's length finance even more. The development of arm's length markets requires better enforcement and more transparency, which will directly hurt incumbents' traditional ways of doing business through contacts and relationships. Consider some examples. In 1991, the Bronfman family was permitted by the Canadian tax authorities to move two billion Canadian dollars to the United States without paying capital gains taxes. When the auditor general complained that the transaction "may have circumvented the intent of the tax code", the government finance committee attacked him for violating the Bronfmans' right to privacy. ${ }^{10}$ In a similar vein, in India borrowers till recently could take money from one state-owned bank, default, and obtain a fresh loan from another stateowned bank. Banks could not share information about defaulters, in part because there was a law (which has recently been superseded) preventing widespread dissemination of information about defaulters. The privacy of defaulters and their right to maintain access to the public till were deemed more important than the public's money, but this is of course natural in an economy dominated by incumbents.

Incumbent financiers may also not fully appreciate change. While financial development provides them with an opportunity to expand their activities, it also strikes at their very source of comparative advantage. In the absence of good disclosure and proper enforcement, any financing that is not against solid collateral is relationship-based. The incumbent financier gathers information from his wide-ranging informal contacts rather than from publicly available sources. He recovers payments not by using the legal system, but by threatening and cajoling, using the many informal levers of power he has developed over the years. Key, therefore, to his ability to lend are his relationships with those who have influence over the firm such as managers, other lenders, suppliers, and politicians. Equally important is his ability to monopolize the provision of finance to a client so that his threat to cut off credit carries weight. Such monopolies are more 
likely if there are no public records of a client's repayment history so that the client is locked in to his financier because only the latter knows his credit history - any other financier approached by the client would be wary of lending, wondering whether he was being approached only because the incumbent financier had deemed the client too risky.

Opaque borrower histories and inadequate legal infrastructure provide formidable barriers to entry behind which the incumbent financier adapts to enjoy large profits. Disclosure and impartial enforcement tend to level the playing field and reduce barriers to entry into the financial sector. The incumbent financier's old skills of being well connected become less important, while new ones of credit evaluation and risk management become necessary. Financial development not only introduces competition, which puts pressure on the incumbent financial institution's profitability and its relationships, it also makes the financier's skills - his human capital -- redundant.

One could also argue for the existence of political incumbents. To the extent that financial development makes matters transparent, and constrains the political favors they can do or the power they have, they may also be opposed.

In short, free markets tend to jeopardize ways of doing business that rely on unequal access. Thus, not only are incumbents likely to benefit less from financial development, they might actually lose. This would imply that incumbents might collectively have a vested interest in preventing financial development and might be a small enough group (Olson (1965), Stigler (1971)) to organize successfully against it.

They may also have the ability to affect policy: Incumbents are a well-defined, focused, small group. In small countries, they have been to the same elite schools, frequent the same clubs, and often intermarry. They may be able to keep finance underdeveloped, because those who benefit most from development, potential entrants, are small, poor, and unorganized while the

\footnotetext{
${ }^{10}$ Cited in Randall Morck, David Strangeland, and Bernard Yeung (2000).
} 
vast ill-informed majority do not know enough, or feel enough pain, to stir out of their complacency.

\subsection{When does finance develop?}

If incumbent industrialists and financiers ordinarily oppose financial development when does it take place? Financial development will take place only when the country's political structure changes dramatically, or when the incumbents want development to take place.

By creating a fresh power structure, political change can foster anti-incumbent institutions, one of which may be financial infrastructure. For example, a number of new mortgage banks and institutions like the Credit Mobilier were supported by the government of Louis Napoleon after its coming to power in 1848 . They were meant as a counter to the Bank of France and the Rothschilds who were thought to be sympathetic to the deposed monarchy (Cameron (1961)). More recently, Weber and Davis (2000) find that a country's transition to a multi-party democracy increases its estimated rate of creation of a stock exchange by $134 \%$ during the subsequent three years.

If, however, we examine a period of relatively little structural political change, we should see finance develop faster when both financial and industrial incumbents will it to do so, and slower when both are against it. When one of these powerful groups is for development, while the other is against, predictions are likely to be more ambiguous.

Incumbent incentives are likely to be powerfully affected by competition, especially that emanating from outside their political borders, which they cannot control. As we show in Rajan and Zingales (2003a), periods when and countries where borders were open to foreign trade and capital coincided with periods of intense financial development. This is true even controlling for the endogeneity of the decision to open up borders.

\subsection{When does arm's-length finance develop?}

Arm's length finance, and the institutions necessary for it, is particularly worthy of opposition for two reasons. First, the creation of those institutions will undermine the 
incumbents' way of doing business and their source of comparative advantage. Incumbents derive their power from their local knowledge and connections, which allow them to get around otherwise Byzantine systems. Better laws, better demarcation of property, and the creation of public credit rating agencies would create a vibrant competitive financial market, bring in outside lenders, and make these skills redundant, thus jeopardizing the fat profits they make. Anticipating this, the incumbent financiers would rather not see the market develop at all. Second, incumbents know that once allowed to flourish arm's length markets are intrinsically hard to tame. Hence, they concentrate their effort on preventing them from taking off.

The infrastructure for arm's length markets stand the best chance to be created when the incumbents' (or the Government) financing needs are so large not to be easily satisfied with traditional arm's length financing. The enormous financing requirements of railroads in the United States (one billion dollars up to 1867 and 10 billion up to 1890) lead to the development of public markets for corporate debt and later for stock. ${ }^{11}$ Financial institutions such as investment banks, including the famous Morgan bank, emerged to underwrite and distribute these securities and to reassure European investors that the money was properly invested. Thus the financing needs of the railroads lead to the creation of financial infrastructure in the United States that was then available to finance other industries that came later. Similarly, to finance the war effort the US government issued over $\$ 21.5$ billions in bonds over two years, at a time when the total amount of corporate securities issued in the previous ten years was only $\$ 16.6$ billion. ${ }^{12}$ To place this large quantity of bonds, commercial and investment banks had to sell to people who had never invested in securities before. From 1917 to 1919 the number of investors who held Treasury bonds exploded from 300,000 to 21 million.

Governments can, perhaps unwittingly, retard or even block the rise of arm's length markets by substituting for some of their functions. For example, in Europe, some governments

\footnotetext{
${ }^{11}$ See Engelbourg and Bushkoff (1996) and Chandler (1990).

12 These figures are from Mahoney (2000)
} 
intervened directly and indirectly in financing the construction of railways. While the stated purpose was to develop local transportation quickly, the perhaps unforeseen effect was to retard the development of a liquid corporate bond market.

Arm's length markets also develop under the pressure of outsiders. The conditions that level the playing filed for outsiders tend also to level the playing field for insiders and increase the level of competition. In this sense the European Union effort to integrate markets has been a natural force in favor of the expansion of arm's length markets.

\section{Political Institutions and Financial Systems}

Arm's length markets cannot flourish without the very visible hand of the government, which is needed to set up and maintain the infrastructure that enables participants to trade freely and with confidence. But who has an interest in pushing the government to create and support this infrastructure? For even though everyone collectively benefits from the better goods, the services, and the equality of access that competitive markets make possible, no one in particular makes huge profits from keeping the system competitive and the playing field level. Thus everyone has

the incentive to take a free ride and let someone else defend the system. A competitive market is a form of public good and, somewhat paradoxically, collective action is needed for its maintenance.

By contrast a relationship-based system has natural political supporters. The opacity and collusive practices that sustain a relationship-based system entrench incumbents at the expense of potential new entrants. In such a system, for example, banks can lock in clients, extracting a rent. This rent provides both the motivation and the resources to fight against an opening up of the system.

This is not to say that the anti-market forces will always prevail even when arm's length markets are much more efficient. It simply says that the political power is naturally biased in favor of retaining, or moving towards, a relationship system. How strong this bias is, however, depends also on the nature of the existing institutions. In what follows we concentrate on two 
institutions that played and will be playing a major role in Europe: the structure of the central bank and the degree of decentralization of political power.

\subsection{Central Bank}

We can view the central bank as simply an industry regulator a la Stigler (1971) or as an independent Government agency, with its own separate objectives, a la Wilson (1989). In both cases the prediction would be the same. Central banks prefer a relationship-based system.

In the traditional Stiglerian approach, the Central Bank, qua regulator of the banking industry, is captured by the interest of the firms it regulates (i.e., the banks). Since we already argued that banks want to preserve their existing monopoly, they will oppose greater transparency, preventing an arm's length market from developing. Clearly, banks' ability to capture the regulator very much depends upon the concentration of the banking industry. A highly concentrated banking sector will have both greater interest and greater ability to influence the central bank against markets.

While Stigler's model has some predictive power, it is often too simplistic. Government agencies are not completely at the mercy of the firms they regulate. As Wilson (1989) argues, pride in one's job and a sense of mission are important factors in motivating regulators and are useful in predicting their behavior. Similarly, Government agencies care greatly about their sphere of power and fight to expand it.

Interestingly, even if we adopt this more nuanced approach, the final conclusion does not change: central banks tend to be anti-market. The function of a central bank, and thus its institutional goals, are twofold: to conduct monetary policy typically with the aim of maintaining price stability and to preserve the stability of the banking system. Both objectives are more easily achieved in a relationship-based system.

As Kashyap and Stein (1997) have argued, an important channel through which monetary policy works is by affecting banks' balance sheet. This affects the supply of bank loans to firms and thus, eventually, the amount of investments. For this channel to work, however, firms have to 
be heavily dependent on bank credit. If they can easily find alternative financing arrangements (such as commercial paper or other market based instruments), central banks will have less power to control credit. Cecchetti (1999) compares the impact on GDP of interest rates changes depending on the type of legal system a country has. He finds that in countries with a German code, monetary policy is almost twice as effective as in countries with a Common Law system. Countries with a French and Scandinavian legal system fall in between. Since La Porta et al. (1998) show that countries with a common law system have more developed markets, Cecchetti's evidence suggests monetary policy is indeed more effective when relationship-financing is more widespread. Thus, central bankers have a natural bias in favor of relationship-based systems. This does not mean central bankers will always oppose markets. The development of a money market, for instance, clearly helps central bankers in their job. We only claim that on average central bankers' attitude will be less pro market, than justified by efficiency considerations alone.

The relationship between central banks' goals and their attitude toward markets is more complex when it comes to the other objective of a central bank: ensuring the stability of the financial system. In normal contingencies a relationship-based system guarantees more stability to the system. Relationships guarantee banks a rent and this rent makes bankers more averse to take wide gambles, which might dissipate those rents. At the same time, free markets introduce more opportunities and these make the job of a regulator more difficult. From both these viewpoints a relationship-based system is preferable for a central banker.

Markets are superior in providing the flexibility to foster disruptive change.

Relationships, as we saw in the Mazda case, are hard to terminate. Hence, banks tend to continue lending to a sector, even when this sector no longer has a future. The absence of informative prices, typical of a relationship-based system, only exacerbates this problem. Hence, in times of major change a farsighted central banker should prefer a more arm's length system, if she recognizes such times are coming. The problem is that the movement from one system to another requires a very long time. A last minute move, without the appropriate infrastructure, could be 
counterproductive. Therefore, it would take an extremely far-sighted central banker to promote markets in the anticipation of a possible disruptive change in the future.

Not only do central banks have a natural bias against markets, they also have a natural bias against institutions that support free markets. Transparency makes their job more difficult as does free capital mobility across countries. Free capital movements restrict a central bank's ability to conduct an independent monetary policy, reducing its discretionary power. Not surprisingly, central bankers have a bias against free capital movements. But, as we show in Rajan and Zingales (2003a), free capital movements are a key force in reducing the incumbents' resistance to the development of arm's length markets.

Finally, in all the above discussion we have assumed that central banks are fully independent from their Government. If they are not, though, their bias in favor of a relationshipbased system only increases. As we already discussed a relationship-based system makes Government intervention less visible and less costly. Thus, the Government will pressure the central bank to maintain a relationship-based system. In addition, in a more opaque system the central bank's supervisory role becomes more powerful, because investors can only rely on the central bank's opinion in deciding where to invest their money. Hence, an interventionist Government able to influence the central bank's actions could use its supervisory function as a powerful tool to surreptitiously direct bank lending toward desired sectors or firms, as did the Nationalist Japanese government in the years before and during World War II.

\subsection{Central vs. local authority}

The second institutional feature we want to analyze in connection to the central bank's attitudes toward arm's length markets is the degree of decentralization of power. A completely decentralized structure, where all the powers reside at the local level, is not good for markets. Arm's length markets enjoy large economies of scale. Thus, at the local level the benefit of creating an arm' length market are very limited. Furthermore, the vested interest against markets 
can more easily lobby a local authority, inducing it to introduce all sorts of anticompetitive restrictions.

To the extent they face external competition, however, local authorities will be more pro markets. If they are unable to restrict legally the competition coming from outside their jurisdiction, they will be forced to update their institutions to allow their firms to survive.

The cause of markets is also greatly enhanced by the formation of common trade areas across countries. First of all, expanding the size of the potential market increases the relative efficiency of an arm's length system, enhancing the cause of markets even at a political level. Second, the need to ensure equal treatment to foreign goods and firms forces an increase in the level of transparency and arm's length dealing, which levels the playing field even for domestic firms. For example, the European Commission has often intervened (most recently in the Volkswagen case) to sanction anti-takeover mechanisms introduced by the national governments in some domestic companies. These interventions were justified in the name of the equal treatment across European states, but had and still have the effect of opening up the market for corporate control. Another advantage of trade zones formed by heterogeneous states is that vested interests tend to be diverse and find it more difficult, at least in the beginning, to get organized and lobby at the super-national level.

Similarly, the conflict of interest between local and central authority will tend to produce more information, and more information is beneficial to the development of arm's length markets. More generally, the conflict between local and central authority naturally creates more freedom. Not surprisingly, the Italian city-states emerged in the shadow of the conflict between the Empire and the Catholic Church and the Euromarket emerged and prospered on the ambiguity of who had to regulate foreign financial institutions domiciled in London.

While market integration across countries is beneficial for the development of markets, political integration might have opposite effects. First of all, the more encompassing the integrated entity, the less external competition it faces. The central political authority, thus, 
regains a monopoly power, amplifying the negative effects of its regulation. Consider an extreme, but illustrative case. Suppose after a severe stock market crash, the European Union decides that too many companies brought to market were little more than a dream and a prayer. It decides to tighten the rules under which companies can issue shares on the market, a move that incumbents across countries might well support because it starves entrants of financing. Given that these rules would apply immediately in all neighboring countries that a new European firm might conceivably think of tapping, that potential entrant might be hard pressed to raise finance under the new rules, making the rules much more effective and making incumbents in each country more eager to press for them with the Union. By contrast, if a single country tried to impose those rules, it would see the potential entrant go to a neighboring country to raise finance. Thus the migration of business to friendlier political entities is a very strong disciplinary force for keeping policies market-friendly. This force is suppressed when neighboring political entities coalesce.

This greatly enhanced regulatory power also increases the incentive for anti-market interest to lobby for protection. In a world where there is political competition, the effect of local legislation can be easily undone by neighboring states, destroying the return to lobbying. In a broader political union, however, this risk is minimized, increasing the return to lobbying. Since the anti-market forces have a comparative advantage in organizing and lobbying, a broader political union can eventually turn out to be more anti-market, as the initially fragmented vested interests coalesce, than a trade zone with weaker political affiliations or a even a loose confederation of states.

\section{European Financial System: Past, Present, and Future}

Now that we have reviewed both the economic and political considerations that lead to the prevalence of different financial system, let us analyze how these considerations shaped the recent history of European financial systems and how they are likely to influence its immediate future.

\subsection{How did Europe Fall Behind?}


The first question we want to address is why, until the beginning of the 1980s, Europe was so much behind in financial development, especially in the development of financial markets. Does it have to do with structural, economic, or cultural differences between Europe and the United States? If so, are these differences likely to persist? Or does this have to do with political considerations? How will these political considerations likely to play in the future?

La Porta et al. (1997) attribute differences to the type of legal system prevailing in different countries (whether the country is based on common law or civil law), while Stulz and Williamson (2001) suggest it is the cultural influences of the dominant religion. While these structural factors could play a role (see later), we think they can be easily overestimated if we do not take a longer historical perspective. This is what we do in Rajan and Zingales (2003a). There we document that not only were the recently observed differences between countries not so stark then, they were quite the reverse before World War I to what we see now. Austria, Belgium, France, Germany, the Netherlands, and Sweden all had bigger equity markets (relative to GDP) than the United States, they had more companies publicly traded per million people and they financed more of their gross fixed capital formation through equity issues. Not all the differences in market development can or should be attributed to deep structural factors. Other forces, which change over time, play an important role. In fact, as we argue in Rajan and Zingales (2003a), structural factors may have influence because of the way they shape and modify political forces rather than because they have a direct influence per se.

Specifically, the important precipitating event was the Great Depression. It triggered a generalized mistrust in the functioning of the market and a demand for political intervention. This demand was at least as strong on the other side of the Atlantic as in Europe. The National Recovery Administration, which was set up under the New Deal, sought to fix prices in industry in order to eliminate "ruinous" competition, while Regulation Q attempted to do the same thing in the banking sector. But the effects on the financial systems were quite different. 
In Europe (and Japan) the 1930s saw a period of repression of markets and massive intervention of the government in the allocation of credit. Taking advantage of the crisis, the government took over the major banks (Italy) or increased its share of deposits (France). Between 1930 and 1937 the share of deposits of public or semi-public institutions grew from 43 percent to 63 percent (Gueslin, 1992). As we discuss in Rajan and Zingales (1993b), many of these interventions proved to be long lasting. In Italy, the Government started to re-privatize the banks only in 1994. As late as 1979, a Bank of France publication reported that 43 percent of all credit to the economy was made with some kind of privilege or subsidy, and 25 percent of corporate lending was subsidized directly (Zysman, 1983). Until the early 1990s, industrial firms in Germany had to obtain approval from the Federal Ministry of Economics for permission to issue commercial paper and long-term bonds. Approval was granted only if the credit standing of the issuer was satisfactory and if the application was supported by a bank.

By contrast, in the United States, the New Deal legislation laid down the foundations for an expansion of markets in the post World War II period. What can explain these differences?

The United States is more federal in character. States have a say, and there is political competition between states. Even though barriers had been erected to the flow of goods across national borders, the United States had a nationwide market for goods and services. So state legislation would not restrain the actions of out-of-state competitors and, thus, could end up only hampering local companies. In addition, powerful local politicians, who favored local incumbents, opposed the centralizing tendencies that were rampant in other countries. This was particularly reflected in the financial arena where there was an old tradition in the United States of opposing the concentration of East coast financial power (Roe, 1994).

Another important difference was the fragmentation of the financial system. As Table 2 shows the United States had by far the least concentrated banking sector. This was no accident. As Roe (1994) argues, this fragmentation has historically been the result of a populist fear of large financial institutions. This fragmentation prevented the United States from going the way of 
Europe and Japan. Investment banks did not see eye to eye with commercial banks, nor did large banks make common cause with small banks. The variety of conflicting private interests and the variety of political support they could count on at both the state and national level, more than any other factor, may have been the reason why outcomes in the United States were not more anticompetitive. There was no way markets could be closed down without hurting some powerful faction in the financial sector.

That the United States escaped the wholesale anti-market changes that took place in other countries does not mean that political interests were not at work. But because political power was more widely distributed, the legislation that emerged did not reflect the interests of just one set of incumbents. For example, small banks obtained federal deposit insurance, which ensured their stability, and capped their funding costs. Large banks had been trying to coordinate limits on deposit interest payments since at least 1905 (Benston, 1994). The Banking Act of 1933 (also known as the Glass Steagall Act) gave them what they wanted by prohibiting interest payments on demand deposits and limiting interest payments for time deposits. Investment banks benefited from the securities and banking legislation passed in 1933 and 1934. Not only were commercial banks prohibited from underwriting corporate securities, but also legislation reduced competition within the investment banking industry (Mahoney (2000)).

At the same time, the populist fear of large financial institutions also retarded the formation of a central bank. Even when this was formed in 1913, it was formed with relatively weak powers. Hence, the Fed was never a strong anti-market force in the United States.

After World War II, two other factors played a role in maintaining the United States more pro market. First, the U.S. financial system emerged from WWII stronger and more efficient than those of the other countries. Hence, U.S. financial institutions had more to gain from open financial markets. Not surprisingly, they played a crucial role in preventing the Bretton Woods agreement from making international capital movements more difficult (see Helleiner (1994)). 
The second factor was the Dollar Exchange System, which prevailed after World War II. Because it allowed for restrictions on international capital movements, the Bretton Woods agreement opened up the possibility of independent monetary policies. Such a possibility, however, was very much linked to the ability of countries to restrict international capital movements and, more generally, all forms of arbitrage international capital arbitrage. This naturally induced an anti-market bias in European central banks. By contrast, the Dollar Exchange System allowed the United States to conduct an independent monetary policy regardless of external consideration. As a result, the U.S. monetary authorities had less to fear from markets.

\subsection{What triggered the change in the 1980s?}

The collapse of the Bretton Wood system in 1971 and the imbalances created by the two subsequent Oil Crises increased dramatically international capital movements, with two important effects on domestic financial systems. First, exchange rates could not be fixed by the government, but had to be credible in the marketplace. This forced tighter fiscal discipline, reducing the scope for the government subsidies that were essential to grease the relationship-based systems.

Second, the possibilities for domestic companies to tap foreign markets for funds, increased the competition in the domestic financial systems, breaking some traditional relationship and forcing domestic intermediaries to develop. For example, in Japan in the early 1980s, corporate bond markets were tiny. This was because commercial banks controlled the socalled "Bond Committee," an official body to which each firm desiring to issue unsecured bonds (bonds that are not backed by collateral) had to apply. Ostensibly, the reason for this arrangement was to ensure that companies marketed only safe issues to the public. The real reason was that banks used the Bond Committee to protect their commercial lending business. Hitachi-then a blue-chip AA-rated firm (AAA being the highest rating) — couldn't obtain permission to issue bonds and thus had to borrow from the banks at high rates. 
The growth of the Euromarket and the opening of Japan's borders to capital flows in 1980 finally loosened the banks' longtime stranglehold on companies. Large Japanese firms now bypassed domestic markets to borrow in the Euromarket. There, they faced no collateral requirements, and they could freely issue a wide range of instruments in different maturities and currencies. Whereas Euromarket issues accounted for only 1.7 percent of Japanese corporate financing in the early 1970s, they accounted for 36.2 percent of it by 1984 . The Bond Committee was forced to disband - not because the government or the banks saw how inefficient it was, but because cross-border competition dictated it.

Improvements in the technology to process and diffuse data also made arm's length markets more appealing, since prices could transmit and aggregate much more information and competition could arise also at a distance.

Finally, the cause of markets was also fostered by the expansion in international trade. As we show in Rajan and Zingales (2003a and 2003b), trade openness generates competition, forcing the development of domestic financial institutions.

Besides this worldwide trend, in Europe some additional factors pushed in favor of markets. The creation of a common market for good and services magnified the effect of a surge in international trade. Not only did the increase in the size of the market enhance the efficiency of an arm's length system, it also changed the underlying political economy. By making more discrete, and thus more politically visible, the choice of the level of openness to trade and capital movements, the European Union made it also more difficult for specific interest groups to lobby for individual protections. The choice was no longer between adhering to the abstract principle of free trade or catering to a powerful interest group (a choice invariably resolved in favor of the latter), but between staying inside the European Union or leaving it, a much more visible, discrete, and politically charged decision.

In fact, membership in the European Union tied governments' hands not only in the granting of special exemption from foreign competition, but in several other directions as well. 
The European Commission deemed subsidies to government-owned firms illegal if they distorted competition across member states. And the fiscal discipline imposed by the EMS system first, and the Euro later, made it impossible for any member state to continue the previously pervasive policies of generalized government credit subsidies. Once this option was eliminated, existing firms started to realize the limitations of the cozy relationship based system directed by the government and started to demand more markets.

Finally, the rules and regulations enacted to make the European market a level playing field for all the member states, contributed to make it a level playing field also for new entrants, increasing competition and destroying many of the pre-existing cozy relationships among incumbents.

\subsection{The impact of the Euro}

What impact, if any, had the introduction of the Euro on this overall change? Since so many factors are at play, it is difficult to isolate the effect of just this variable. Nevertheless, we attempt to do so by looking at the market for corporate debt. One confounding factor is the contemporaneous surge in financing needs of telecommunication companies (ECB, 2001). For this reason we have to identify the level of bond issues for countries that adopted the Euro and countries that did not.

Unlike Detken and Hartmann (2002) we are not interested in the share of bonds issued in euro, but how the introduction of the Euro has changed the importance of corporate bond financing in the individual countries. This is the market where the impact of a common currency should have been felt the most. National currencies were segmenting the corporate bond market in Europe. On the one hand, firms were reluctant to issue large amount of long-term bonds denominated in foreign currencies, because of the exchange risk involved in repayments. On the other hand, the demand for bonds denominated in national currencies was limited because 
institutional investors, such as pension funds, had to face exchange risk as well. Can we thus observe an increase in the amount of corporate debt following the introduction of the euro?

The data assembled by the Bank of International Settlement allows us to answer this question. The BIS data has the amount of domestic corporate debt outstanding in each country since 1989 and international corporate debt by country of issuer since 1993 . With these data we can compute the net debt issues as a first difference. We then normalize it by the GDP. In Table $8 \mathrm{a}$ we report the summary statistics for domestic net debt issues, international net debt issues and the sum of the two.

In Table $8 \mathrm{~b}$ we regress these different measures of debt issues on country and year dummies and an indicator variable equal to one in the countries that adopted the euro in the years subsequent to the introduction of the euro. As Table $8 \mathrm{~b}$ shows, regardless of the measure used, the introduction of the euro had a positive and statistically significant effect on the amount of net debt issues. The effect is quantitatively very large: the amount of debt issues almost triple after the introduction of the euro. This effect can be graphically be seen in Figure 4, where we plot the average total net debt issues in countries who adopted the euro and in countries that did not, both before and after the introduction of the euro. Before the adoption of the Euro Euro-regioncountries had average total net debt issues of almost zero, while non-Euro countries had an average of $1 \%$ of GDP. After the introduction of the Euro, non-Euro countries remained at that level, while Euro countries jumped to net issues of $2 \%$ of GDP per year. These results are consistent with Santos and Tsatsaronis (2002), who find a decrease in the underwriting fees following the introduction of the Euro.

In sum, the Euro seems to have had an independent effect in promoting the development of arm's length markets in countries that adopted it. The effect is quantitatively very large.

\subsection{Is this trend likely to continue?}

In the last two decades two major forces contributed to the development of markets in Europe: the increased openness of the worldwide economy and the process of economic and 
political integration taking place in Europe. Both these forces are unlikely to be as strong in the near future.

As we argue in Rajan and Zingales (2003a), free movement of goods and capital. is essential to keep in check the local vested interests who want to repress finance and in particular arm's length finance. But the political consensus in favor of free trade and free capital movement is eroding, under the effect of international crises and the antiglobalization movement (e.g. Stiglitz, 2002). The possibility of a new reversal in financial development is made more likely by the new intellectual climate triggered by the fall out of the Internet bubble and by the highly publicized corporate scandals in the United States, all of which creates a fertile domestic anti-market political climate. When coupled with the increasing willingness of politicians to sacrifice free trade for political expediency (see e.g. Bush's steel tariffs), the political climate does not look good for the expansion of markets.

At the same time, the positive benefits of the process of European integration may be running their course and further integration might actually start to exercise a negative influence. The more power that will be transfer from local government to the Union, the more it will become a monopolist, attractive prey for incumbents who want to solidify their economic power by repressing financial development.

\subsection{What is the right system for Europe?}

Before we start worrying, however, we need to make the case that a further development of arm's length markets is indeed in the interest of European economies. But this is not an easy task. At the end of the 1980s, many Western economists, impressed by the successes of the Japanese economy, were chanting the praise of the relationship-based system. There were repeated calls for the U.S. to adopt new laws that would permit financiers to take a longer view of their investments, and to move toward the more relationship-based investing model that prevails in Japan (Porter, 1992). In 1998 the same system was relabeled "crony capitalism" and became 
the scapegoat for the East Asian crisis. Now the pendulum is swinging back. It is only the sorry plight of Japan, laid low by a lost decade of government ineptitude that keeps academics from extolling the virtues of a more managed relationship-based economy once again.

As we explained in Section 2, the trade-offs between the systems are complex. A relationship-based system could be the best option during certain phases of development and could be inadequate for others. Till the 1970s, relationship-based systems such as Germany, Japan and France, had much higher growth rates than market based-systems of the United Kingdom and the United States. In the last ten years the ranking has been reversed. The United States grew at a 3.8 percent annual rate, England at 3.4 percent, while France grew at 2.8 percent, Germany at 1.9 percent, and Japan at a paltry 1.2 percent rate. ${ }^{13}$

Rather than making a blanket judgment about the superiority of one system over the other, it makes more sense to qualify it based on the environmental conditions each country faces. To begin with, the relative benefits of an arm's length system have been increased by the process of European integration, culminated with the introduction of the Euro. While the process of international integration has removed many barriers to entry, enhancing both national and international competition, the introduction of the Euro has removed many of the remaining economic and psychological barriers. European countries now face a large integrated market, where information can travel freely as can competition. Since it is intrinsically opaque, a relationship-based system, cannot take full advantage of these new opportunities, while an arm's length system can.

The stage of development of most European countries also favors arm's length systems. Since many are close to the world technological frontier, they face uncertainty on where best to invest their resources (and where best to divest them). In this phase they can greatly benefit from the information that prices convey in an arm's length system (see Rajan and Zingales (1998a)).

\footnotetext{
${ }^{13}$ Author's calculations from the IFS statistics.
} 
Of course, this benefit is relatively more important for the more developed Northern European countries, than for the less developed Southern ones.

The changes that firms are undergoing in developed countries also favor an arm's length system. As we discussed in Rajan and Zingales (2000) physical capital is becoming less important, while human capital is taking the center stage. Relationship based systems find it more difficult to finance human capital firms, especially when these human capital-intensive firms are involved in disruptive innovation. Hence the relative benefit of an arm's length system may grow as firms change their nature.

But probably the most important factor playing in favor of arm's length markets is the phase of technological innovation we are currently living. The last decade has been characterized by what management scholars label "disruptive innovation". While the dislocation stemming from technological change is not new, its pace and magnitude have increased tremendously. As we already discussed, a relationship-based system finds it difficult to finance this innovation. It also finds it extremely difficult to stop financing obsolete firms. Technological change also affects the demand for human capital: traditional skills become rapidly obsolete, while new ones are needed. This requires greater human capital mobility, across firms, and across sectors, which a relationship-based system will find harder to facilitate. Overall, thus, several environmental factors favor arm's length systems.

In developing the transparent legal, regulatory, and supervisory infrastructure to govern arm's length markets, however, Europe trails the United States. Furthermore, European countries differ greatly in their preparedness. In Table 9, we report the levels of some common indictors of quality of laws, law enforcement, and transparency. In the first two columns we report the La Porta et al. (1998) indicator of quality of law protecting arm's length investors (shareholders and creditors). The first is an indicator of the rights minority shareholders have to challenge the incumbent managers. While the United States has a perfect score of 5, the European's score is less than half (2.3). But European countries score better as far as creditors' rights are concerned: 
on average they have a score of 2 out of five versus a U.S. score of 1. In both cases, however, Northern European countries (Austria, Belgium, Denmark, Finland, France, Germany, Ireland, Luxembourg, Netherlands, Sweden, U.K.) have a much higher score than Southern European countries (Greece, Italy, Portugal and Spain).

The backwardness of European infrastructure, and in particular of the Southern European infrastructure, is more evident when we look at measures of effective enforcement. Djankov et al. (2002) have computed the time it takes to collect a bounced check and to evict a tenant who does not pay rent in different countries, which we report in column 3 and 4. While in the United States it takes only 54 days in Europe it takes on average 227 days. But this average hides an enormous difference within Europe. In Northern European countries the average is 171 days, while in Southern European countries is 382 . In many countries, however, checks are not used as a standard mean of payment, thus this figure may not be very relevant. The same result, however, emerges if we focus on the total number of days it takes to evict a tenant who does not pay. While in the United States it takes only 49 days, in Europe it takes five times as much. Once again, however, there is a big difference between Southern and Northern Europe (348 vs. 202).

Survey-based measures of the quality of legal enforcement lead us to the same conclusion. In column 4 we report the level of judicial efficiency, which is an assessment, produced by country risk rating agency Business International Corp, of the "efficiency and integrity of the legal environment as it affects business, particularly foreign firms". In column 5 we report the "assessment of the law and order tradition in the country" produced by the country risk rating agency International Country Risk (ICR).

In both these measures Europe trails the United States: judicial efficiency is rated on average 8.2 vs. 10 out of 10 for the United States, and law and order is rated 9 in Europe vs. 10 for the United States. But more significant is the divide between Northern and Southern Europe. While Northern European countries have an average score very similar to that of the U.S. (9.5 
both in judicial efficiency and in rule of law), Southern European countries (Greece, Italy, Spain and Portugal) have a score of only 6.4 in the first and 7.8 in the second.

Arm's length systems need publicity. Thus, any institutional incentive to hide information is very detrimental. When corruption and tax evasion are widespread, insiders have a strong interest in hiding information, to facilitate tax evasion or the payment of bribes. While in these two dimensions the relative performance of Europe and the United States is similar, the differences in performance between Northern and Southern Europe is again remarkable.

We measure corruption with a survey-based index produced by risk rating agency International Country Risk (ICR), where lower scores indicate that "high government officials are likely to demand special payments". While Europe on average has a better corruption record than the United States, Southern Europe has a much lower score than Northern Europe (7 vs. 9.3) and the States. The same is true for the quality of the tax enforcement. As a measure of the effectiveness of the taxation system we use an index developed by the World Competitiveness Report, which assesses the level of tax compliance. The index goes from 0 to 6 where higher scores indicate higher compliance. Along this dimension the United States perform much better than Europe (4.5 vs. 3), but once again the major divide is between Northern and Southern Europe.

Much of the benefits of an arm's length system come from the dissemination of information. If information is not produced and disclosed, however, these benefits do not materialize. Also in this dimension there is an important difference between the United States and Europe and within Europe itself. The Center for International Financial Analysis and Research has produced in 1990 an index of quality of accounting disclosure, by examining and rating companies' 1990 annual reports on their inclusion or omission of 90 items. United States companies report on average 71 of the 90 items, European companies only 64 . But once again this average hides the within Europe difference. Companies from Northern European countries 
report 68 items while companies from Southern Europe only 54 (only slightly more than half of the items they should be reporting).

The reader might be legitimately suspicious of these indicators, since they mostly rely on surveys and attempt to measure the quality of the regulatory framework by looking at the input (laws and regulations) and not at the economic output. However, we arrive at a similar conclusion if we focus on an outcome-based measure. Arm's length markets can develop only when insiders cannot appropriate too much value at the expense of insiders. Dyck and Zingales (2003) produce a cross-country estimate of the value captured by insiders in different countries (their measure is the premium controlling shareholders pay to acquire control in a publicly traded company - an indication of what they can extract from the company at the expense of public shareholders). We report these estimates in the ninth column of Table 9. Here we note a remarkable difference between the United States and Europe. While in the United States insiders can appropriate on average only 1 percent of the value of a company, in Europe they appropriate 12 percent. Once again, there is a great divide between North and South. In Northern European countries the value appropriated is only 9 percent, while in Southern European countries it is 20 percent.

Finally, in our theoretical analysis we highlighted the existence of an interaction between a firm's organizational structure and its ability to take advantage of arm's length markets. Bigger, more formally organized, firms naturally produce more information and hence, they can more easily disseminate it. Also on this dimension there is a remarkable difference between Northern and Southern Europe. The average size of an enterprise is 10 people in Northern Europe, but only 5 in Southern Europe. ${ }^{14}$

In sum, technological and market considerations suggest that during this economic phase an arm's length system is to be preferred. Europe, however, lags behind in the creation of the legal and regulatory infrastructure that allows arm's length markets to function and this gap is 
particularly pronounced in Southern Europe. For effective arm's length markets to develop, there is a serious need of reforms.

There is a serious danger that reforms facilitating markets will benefit Northern Europe and the more developed regions of Southern Europe but can bypass or even harm the underdeveloped regions of Southern Europe, which do not have the necessary institutions to take advantage of markets. As Guiso et al. (2002) have shown, monetary and even political integration are not sufficient to obtain an effective integrated market. Within Italy, significant differences exist in the quality of the law enforcement between the North and South. This is associated with enormous differences in the ability to obtain financing: an entrepreneur is twice as likely to be denied financing in certain areas than in others. As Guiso et al. (2002) argue, this difference might be at the root of enormously different levels of economic development.

This suggests that a move towards markets can exacerbate differences between countries and, more importantly, within countries. In order for Southern Europe to take full advantage of markets and ensure the benefits are spread widely, it is important that the institutions supporting markets be strengthened across the board. But till this is done, some regions may not see the benefits of markets while, at the same time, they will face the loss of the relationship system. This will increase political tensions and increase the divide between various constituencies such as small and large firms, regional and national banks, etc.

In sum, we believe despite the current anti-market climate the relevant question is not whether Europe should be moving toward an arm's length system. It should. The real question is whether there is the political will to move in that direction and, more importantly, whether countries can improve their internal infrastructure so that they can benefit fully from this move.

\subsection{How to prevent a new reversal?}

\footnotetext{
${ }^{14}$ The data are from Kumar et al. (2000). From their list we omit Austria, because it reports only 8 sectors, and Greece, which reports statistics only for enterprises with more than 10 employees. Including the data for Austria (average of 63 employees) will only exacerbate the divide.
} 
In Rajan and Zingales (2003b) we discuss a number of possible policies aimed at ensuring an enduring public consensus in favor of markets and reducing incumbents' interest and incentives to repress them. Besides awareness, these policies include a reform of the taxation system aimed at penalizing inefficient owners and a safety net aimed at protecting individuals rather than the existing institutions. Instead of repeating these suggestions, in this context we ask what implications our approach has for the current debate on the institutional future of Europe. Since the issues at stake are very complex, we analyze them only from one point of view: their impact on the development of arm's length markets. This is clearly a partial view, but one which needs to be taken into consideration in the overall debate.

Probably the most important political decision facing Europe right now is the tradeoff between an enlargement of its borders and acceleration of the political union. From a financial market perspective, the first option is vastly superior. Enlargement will increase economic competition, reducing the resistance to financial markets. At the same time, the introduction of new divergent interests inside the European Union will make coordination and lobbying more difficult, reducing the political threats to markets. By contrast, further steps toward political integration will reduce political competition and strengthen the central authority, increasing the return to lobbying at the central level. Both these effects will tend to reduce the political support for markets.

Another crucial topic in the institutional debate is the unanimity rule adopted at the European Commission level. Many people question the viability of such a rule in the future, especially in face of an enlargement. While not ignoring the costs of a decision making process based on unanimity, we also see its benefits. A unanimity rule makes it more difficult for a central authority to exercise its monopoly power, reducing the risk that it will be used against markets. Unanimity rules preserve the status quo. To the extent the status quo is biased towards markets, it prevents speedy reversal. 
Finally, a central issue in the institutional debate is the allocation of the authority to supervise banks. Our analysis suggests different answers depending on the nature of the power allocated. On the one hand, leaving merger reviews to national institutions impedes the formation of a European level market for corporate control in banking. On the other hand, centralizing the supervisory function will rejoin the role of supervisor and lender of last resort increasing the ECB's powers of moral suasion, which future European government might use to direct the allocation of credit or the rescue of favored banks. By contrast, maintaining a division of roles and even some conflicts of jurisdiction will reduce the power of both institutions to the larger good of markets. ${ }^{15}$

\section{Conclusions}

In the last twenty years the European financial system has become more market-based. This movement has been the result of a fortunate coincidence of favorable international conditions (increase in international trade and capital movements), economic conditions (improvements in processing and transmission of information that have made arm's length markets more efficient) and local political conditions (the transition from separate national governments to a more unified European government).

While the economic conditions in favor of arm's length markets do not seem to have changed, the political conditions favoring them have. The anti-globalization movement is creating a political movement for protectionism and politicians in both the United States and Europe have started pandering to it. The revelations of corporate scandals in the United States has undermined the moral standing of market-based economies at a time when the bursting of the Internet bubble is weakening its economic credibility, strengthening anti-market forces worldwide. In Europe, these forces may find additional support from the distributional effects of the movement towards markets, which benefits less (or perhaps even penalizes) regions in Southern Europe. Finally, we

\footnotetext{
${ }^{15}$ For an in depth analysis on this topic see Carretti and Hartmann (2002).
} 
argue that the completion of the economic integration and the beginning of the political integration might trigger a shift in the pro-market stand of the European Union.

Our analysis has clear implications on what the European Union should do to buck this anti-market trend. First, it should promote structural reforms in Southern European countries, in order to reduce the distributional effects of an expansion of arm's length markets. Second, it should focus on enlargement of the Union, to increase economic competition. Finally, it should maintain a division of power between local and central authorities at all level, including the central bank ones, to prevent a reduction in political competition. 


\section{References}

Allen, F., (1993) Stock markets and resource allocation. In: Mayer, C., Vives, X. (Eds.), Capital Markets and Financial Intermediation. Cambridge University Press, Cambridge.

Allen, F. and D. Gale (1995), "A Welfare Comparison of Intermediaries and Financial Markets in Germany and the US” European Economic Review 1995, p 179-209.

Allen, F. and D. Gale (1997), "Financial Markets, Intermediaries, and Intertemporal Smoothing", Journal of Political Economy June 1997.

Allen, F. and D. Gale (2000), Comparing Financial Systems, MIT Press, Cambridge MA.

Barth, James, Dopico Luis G, Daniel E. Nolle, J. Wilcox, (2002) “An International Comparison and Assessment of the Structure of Bank Supervision”, UC Berkeley Working Paper.

Benston, G., 1994. The origins and justification for the Glass Steagall Act. In: Saunders, A., Walter, I., Universal Banking in the United States: What Could We Gain? Oxford University Press, New York, Pages 31-69.

Black, B., Gilson, R., (1998) "Venture capital and the structure of capital markets: bank versus stock markets. Journal of Financial Economics 47:243-277.

Black, S. and Philip Strahan, 2002, "Entrepreneurship and Bank Credit Availability", Journal of Finance.

Bottazzi, L. and M. Da Rin, (2002) “European Venture Capital” Economic Policy April, p. 231-269.

Bhattacharya, U., Daouk, H., (2002) “The world price of insider trading”, Journal of Finance 57, 75108.

Cameron, R. 1961. France and the Economic Development of Europe, 1800-1914. Princeton University Press, Princeton.

Carletti, Elena and Philipp Hartmann, (2002) "Competition and Stability: What's Special About Banking”, ECB Working Paper \#146.

Carlin, W., and Mayer, C. (1998), 'Finance, Investment and Growth,' University College (London), Working Paper.

Cecchetti, Stephen, 1999, "Legal Structure, Financial Structure, and the Monetary Policy Transmission Mechanism”, FRBNY Economic Policy Review, July 9-27.

Chandler, A., 1990. Scale and Scope: The Dynamics of Industrial Capitalism. Belknap Press, Cambridge.

Detken, C. and P. Hartmann, (2002), "Features of the Euro's role in international financial markets" Economic policy, Fall 2002.

Diamond, D. W., and P. Dybvig, (1983), "Bank runs, deposit insurance and liquidity." The Journal of Political Economy, 91, 401-419. 
Diamond, D. W., and Rajan, R. G. (2001a), 'Liquidity Risk, Liquidity Creation and Financial Fragility: A Theory of Banking,' The Journal of Political Economy, 109(2), 287-327.

Diamond, D. W., and Rajan, R. G. (2001b), 'Banks, Short-Term Debt, and Financial Crises: Theory, Policy Implications, and Applications,' Carnegie Rochester Conference on Public Policy, 54 (Summer), 37-71.

Djankov, S. Rafael La Porta, Florencio Lopez-de-Silane, Andrei Shleifer, 2002, "Lex Mundi Courts: the Lex Mundi Project”, NBER Working Paper.

Dyck, A. and L. Zingales (2003) "Private Benefits of Control: An International Comparison”, Journal of Finance, forthcoming.

Engelbourg, S. and L. Bushkoff, 1996, The man who found the money : John Stewart Kennedy and the financing of the western railroads. East Lansing : Michigan State University Press

European Central Bank, (2001), Characteristics of corporate finance in the Euro Area, ECB Monthly Bulletin, February 2001.

Gompers, P. A. (1995), 'Optimal Investment, Monitoring, and the Staging of Venture Capital,' The Journal of Finance, 50(5), 1461-89.

Gorman, M. and W. Sahlman, 1989, "What do venture capitalists do?" Journal of Business Venturing 4:231-248.

Grossman, Richard S., 1994, “The Shoe that Didn't Drop: Explaining Banking Stability During the Great Depression", The Journal of Economic History, Vol. 54, N. 3, September 654-682

Guiso, L, P. Sapienza and L. Zingales, 2002, “Does Local Financial Development Matter?” NBRE Working paper.

Gueslin, A., 1992, "Banks and State in France from 1880s to the 1930s: the impossible advance of the banks" in Y. Cassis Finance and Financiers in European History, 1880-1960, Cambridge University Press.

Helleiner E., 1994. States and the Reemergence of Global Finance: From Bretton Woods to the 1990's. Cornell University Press, Ithaca.

Hellwig, M, 2000. On the economics and politics of corporate finance and corporate control. In: Vives, X. (Ed.), Corporate Governance: Theoretical and Empirical Perspectives. Cambridge University Press, Cambridge, pp. 95-136.

Houston, J., and James, C. (1996), 'Bank Information Monopolies and the Mix of Private and Public Debt Claims,' The Journal of Finance, 51(5), 1863-90.

Hoshi, T., Kashyap, A., and Scharfstein, D. (1990a), 'Bank Monitoring and Investment: Evidence from the Changing Structure of Japanese Corporate Banking Relationships,' in R. G. Hubbard (ed.), Asymmetric Information, Corporate Finance and Investment, Chicago, The University of Chicago Press. 
Hoshi, T., Kashyap, A., and Scharfstein, D. (1990b), 'The Role of Banks in Reducing the Costs of Financial Distress in Japan,' Journal of Financial Economics, 27, 67-88.

Hoshi, T., Kashyap, A., and Scharfstein, D. (1991), 'Corporate Structure, Liquidity, and Investment: Evidence from Japanese Panel Data,' The Quarterly Journal of Economics, 27, 33-60.

Jayaratne, J., and Strahan, P. E. (1996), 'The Finance-Growth Nexus: Evidence from Bank Branch Deregulation,' The Quarterly Journal of Economics, 111(3), 639-71.

Jensen, Michael C., (1986), 'Agency Costs of Free Cash Flow, Corporate Finance and Takeovers,' American Economic Review 76, 323-39.

Jensen, M., and Meckling, W. (1976), 'Theory of the Firm: Managerial Behavior, Agency Costs and Capital Structure,' Journal of Financial Economics, 3, 305-60.

Johnson, S., McMillan, J., Woodruff, C., 2000. Courts and relational contracts. Unpublished working paper. M.I.T, Cambridge.

Kashyap, A., D. Weil, and D. Scharfstein, D. (1990), "The high price of land and the low cost of capital: Theory and evidence from Japan", MIT Working Paper.

Kashyap and Stein (1997) The Role of Banks in Monetary Policy: A Survey With Implications for the European Monetary Union", Federal Reserve Bank of Chicago Economic Perspectives, September/October 1997, pp. 2-18.

King, R. G., and Levine, R. (1993), 'Finance and Growth: Schumpeter Might Be Right,' The Quarterly Journal of Economics, 108(3), 717-37.

Kumar, K.,R. Rajan, and L. Zingales, 2000, "What Determines Firm Size?" University of Chicago Working Paper.

Kukies, J. , "Stock Markets for High Technology Firms and Venture Capital Financing: Evidence from Europe", University of Chicago Ph.D. Dissertation.

Lamont, O., Thaler, R., 2001. Can the market add and subtract? Mispricing in tech-stock carve-outs. Unpublished working paper. The University of Chicago, Chicago.

La Porta, R., Lopez de Silanes, F., Shleifer, A., and Vishny, R. (1997), 'The Legal Determinants of External Finance,' Journal of Finance, 52(3), 1131-50.

La Porta, R., Lopez de Silanes, F., Shleifer, A., and Vishny, R. (1998), 'Law and Finance,' Journal of Political Economy, 106, 1113-55.

La Porta, R., Lopez de Silanes, F., Shleifer, A (1999), 'Corporate Ownership around the World,' Journal of Finance.

Levine, R. (1997), 'Financial Development and Economic Growth: Views and Agenda,' Journal of Economic Literature, 35(2), 688-726. 
Levine, R. (1999), 'Law, Finance and Economic Growth,' Journal of Financial Intermediation, 8 (1).835.

Levine, R., and Zervos, S. (1998), 'Stock Markets, Banks, and Economic Growth,' The American Economic Review, 88(3), 537-58.

Mahoney, P. G. (2000), The political economy of the Securities Act of 1933. Social Science Research Network, working paper \# 00-11.

Julian Franks and Colin Mayer , "Bank control, takeovers and corporate governance in Germany", Journal of Banking \& Finance, 1998, 22: 1231-1480.

Morck,R. David Strangeland, and Bernard Yeung (2000). , "Inherited Wealth, Corporate Control, and Economic Growth: The Canadian Disease?", p. 347 in R.K. Morck, Concentrated Capital Ownership, University of Chicago Press, 2000

Morck, R, Yeung, B., and Yu, W. (2000), 'The Information Content of Stock Prices: Why Do Emerging Markets Have Synchronous Stock Price Movements?,' Journal of Financial Economics, 58(1,2), 215-60.

Novaes, W. and L. Zingales "Bureaucracy as a Mechanism to Generate Information", 1998, University of Chicago Working Paper.

Olson, M., (1965) The Logice of Collective Action: Public Goods and the Theory of Groups. Harvard University Press, Cambridge.

Peek, J., and Rosengren, E. S. (1998), 'The International Transmission of Financial Shocks: The Case of Japan,' The American Economic Review, 87(4), 495-505.

Petersen, M. A., and Rajan, R. G. (1995), 'The Effect of Credit Market Competition on Lending Relationships,' The Quarterly Journal of Economics, 110(12), 407-43.

Porter, M., (1992) "Capital Choices: Changing the Way America Invests in Industry," Journal of Applied Corporate Finance, Vol. 5 No. 2 (Summer 1992), pp. 4-16.

Prowse, S., 1996. Alternative models of financial system development. RBA Annual Conference Volume 1996-06, Federal Reserve Bank of Australia, Sydney.

Rajan, R., and Zingales, L. (1995), 'Is there an Optimal Capital Structure? Some Evidence from International Data,' Journal of Finance, 50, 1421-60.

Rajan R. G., and Zingales, L. (1998a), 'Which Capitalism? Lesson from the East Asian Crisis,' The Bank of America Journal of Applied Corporate Finance, 11(3), 40-48.

Rajan R., and Zingales, L. (1998b), 'Financial Dependence and Growth,' American Economic Review, 88, 559-86. 
Rajan R., and Zingales, L. (2001a) "The Influence of the Financial Revolution on the Nature of Firms" American Economic Review (2001), 91: 206-212.

Rajan R., and Zingales, L. (2001b) "Financial Systems, Industrial Structure, and Growth," Oxford Review of Economic Policy, 2001 17: 467-482.

Rajan, R., Zingales, L., (2001c) The firm as a dedicated hierarchy: a theory of the origins and growth of firms. Quarterly Journal of Economics 116, 805-852.

Rajan R. G., and Zingales, L. (2003a), 'The Great Reversals: The Politics of Financial Development in the 20th Century,' Journal of Financial Economics, forthcoming.

Rajan R. G., and Zingales, L. (2003b), Saving Capitalism from the Capitalists Crown Books, Random House, New York, NY.

Roberts, Dan (2001) “Glorious Hopes on a Trillion-Dollar Scrapheap”, Financial Times, September 5.

Roe, M. J., 1994. Strong Managers, Weak Owners: The Political Roots of American Corporate Finance. Princeton University Press, Princeton.

Rydqvist, K. and Kenneth Hogholm, "Going Public in the 1980s: Evidence from Sweden”, European Financial Management, 1995, Vol 1, N.3: 287-315

Sah, R., Stiglitz, J., 1986. The architecture of economic systems: hierarchies and polyarchies. The American Economic Review 76(4): 716-727.

Santos, J. A. C. and K. Tsatsaronnis, (2002), "The Cost of Barriers to Entry: Evidence from the Market for Corporate Euro Bond Underwriting”, NYFED Working Paper.

Schumpeter, J. A. (1911), A Theory of Economic Development, Cambridge, MA, Harvard University Press.

Seligman, J. (1995), The Transformation of Wall Street, Boston, MA, Northeastern University Press, 42.

Stigler, G., 1971. Theory of economic regulation. Bell Journal of Economics 2, 3-21.

Stiglitz, J. E., 2002. Globalization and Its Discontents. W. W. Norton, New York

Stulz, R., Williamson, R., 2001. Culture, openness, and finance. Unpublished working paper 8222, NBER, Cambridge.

Weber, K., Davis, G., 2000. The global spread of stock exchanges 1980-1998. Unpublished working paper. University of Michigan.

Wilson, James Q, 1989, Bureaucracy, BasicBooks.

Wurgler, J. (2000), 'Financial Markets and the Allocation of Capital,' Journal of Financial Economics, $58(1,2), 187-214$. 
Zysman, J., 1983. Governments, markets, and growth: finance and the politics of industrial change. Cornell University Press, Ithaca. 


\section{Table 1}

\section{Different Indicators of Financial Development in 1980}

Bank loan to the private sector is the ratio of claims on private sector of deposit money banks (line 22d International Financial Statistics) and GDP. Deposits to GDP is the ratio of commercial and savings bank deposits (lines 24 and 25 of International Financial Statistics) and GDP. Stock market Cap to GDP is the aggregate market value of equity of domestic companies divided by GDP. Number of companies to population is the ratio of number of domestic companies whose equity is publicly traded in a domestic stock exchange and the country's population in millions. Equity issues to GFCF is the ratio of funds raised through public equity offerings (both initial public offerings and seasoned equity issues) by domestic companies to gross fixed capital formation. Source: IMF and Rajan and Zingales (2003a).

\begin{tabular}{|c|c|c|c|c|c|}
\hline Country & \begin{tabular}{|c|} 
Bank Loan \\
to Private \\
Sector \\
\end{tabular} & Deposits & $\begin{array}{c}\text { Stock } \\
\text { Market } \\
\text { Cap. }\end{array}$ & $\begin{array}{l}\text { Equity } \\
\text { issues }\end{array}$ & $\begin{array}{c}\text { N. of } \\
\text { companies }\end{array}$ \\
\hline AUSTRIA & 0.742 & 0.682 & 0.030 & 0.000 & 8.740 \\
\hline BELGIUM & 0.272 & 0.299 & 0.090 & 0.030 & 22.850 \\
\hline DENMARK & 0.244 & 0.276 & 0.090 & 0.010 & 42.540 \\
\hline FINLAND & 0.462 & 0.391 & na & 0.012 & na \\
\hline FRANCE & 0.731 & 0.679 & 0.090 & 0.060 & 13.990 \\
\hline GERMANY & 0.864 & 0.564 & 0.090 & 0.010 & 7.460 \\
\hline GREECE & 0.520 & 0.507 & 0.085 & na & na \\
\hline IRELAND & 0.315 & 0.577 & na & na & na \\
\hline ITALY & 0.555 & 0.676 & 0.070 & 0.040 & 2.360 \\
\hline LUXEMBOURG & 1.210 & 1.626 & 0.001 & 0.016 & 205.556 \\
\hline NETHERLANDS & 0.632 & 0.602 & 0.190 & 0.010 & 15.120 \\
\hline PORTUGAL & 0.855 & 0.946 & 0.006 & na & na \\
\hline SPAIN &. & 0.723 & 0.087 & 0.028 & 13.213 \\
\hline SWEDEN & 0.415 & 0.510 & 0.110 & 0.000 & 12.390 \\
\hline Average Cont. Europe & 0.601 & 0.647 & 0.078 & 0.020 & 34.422 \\
\hline UK & 0.276 & 0.280 & 0.380 & 0.040 & 47.220 \\
\hline US & 0.354 & 0.540 & 0.460 & 0.040 & 23.110 \\
\hline $\begin{array}{l}\text { Average Anglo- } \\
\text { American }\end{array}$ & 0.315 & 0.410 & 0.420 & 0.040 & 35.165 \\
\hline
\end{tabular}




\section{Table 2 \\ Different Indicators of Financial Development in 2000}

Bank loan to the private sector is the ratio of claims on private sector of deposit money banks (line 22d International Financial Statistics) and GDP. Deposits to GDP is the ratio of commercial and savings bank deposits (lines 24 and 25 of International Financial Statistics) and GDP. Stock market Cap to GDP is the aggregate market value of equity of domestic companies divided by GDP. Number of companies to population is the ratio of number of domestic companies whose equity is publicly traded in a domestic stock exchange and the country's population in millions. Equity issues to GFCF is the ratio of a three year average (1999-2001) of funds raised through public equity offerings (both initial public offerings and seasoned equity issues) and domestic companies to gross fixed capital formation. Source: FIBV, IMF, and Rajan and Zingales (2003a).

\begin{tabular}{|l|c|c|c|c|c|}
\hline Country & $\begin{array}{c}\text { Bank Loan } \\
\text { to Private } \\
\text { Sector }\end{array}$ & Deposits & $\begin{array}{c}\text { Stock } \\
\text { Market } \\
\text { Cap. }\end{array}$ & $\begin{array}{c}\text { Equity } \\
\text { issues }\end{array}$ & $\begin{array}{c}\text { N. of } \\
\text { companies }\end{array}$ \\
\hline AUSTRIA & 1.040 & 0.819 & 0.156 & 0.051 & 11.975 \\
\hline BELGIUM & 0.792 & 0.837 & 0.783 & 0.138 & 15.707 \\
\hline DENMARK &. &. & 0.686 & 0.192 & 42.135 \\
\hline FINLAND & 0.534 & 0.464 & 2.383 & 0.497 & 29.730 \\
\hline FRANCE & 0.864 & 0.636 & 1.087 & 0.145 & 13.720 \\
\hline GERMANY & 1.207 & 0.925 & 0.668 & 0.065 & 9.071 \\
\hline GREECE & 0.526 & 0.566 & 0.942 & 0.430 & 30.869 \\
\hline IRELAND & 1.069 & 0.793 & 0.843 & 0.172 & 20.053 \\
\hline ITALY & 0.770 & 0.514 & 0.703 & 0.041 & 5.058 \\
\hline LUXEMBOURG & 1.099 & 3.367 & 1.771 & 0.494 & 122.727 \\
\hline NETHERLANDS & 1.398 & 0.963 & 1.701 & 0.629 & 14.754 \\
\hline PORTUGAL & 1.408 & 0.997 & 0.567 & 0.502 & 10.889 \\
\hline SPAIN & 1.012 & 0.816 & 0.882 & 0.866 & 25.817 \\
\hline SWEDEN & 0.457 & 0.391 & 1.476 & 0.289 & 32.920 \\
\hline $\begin{array}{l}\text { Average Cont. } \\
\text { Europe }\end{array}$ & 0.937 & 0.930 & 1.046 & 0.322 & 27.530 \\
\hline & & & & & \\
\hline UK & 1.320 & 1.069 & 1.840 & 0.149 & 32.370 \\
\hline U.S. & 0.493 & 0.379 & 1.549 & 0.207 & 25.847 \\
\hline $\begin{array}{l}\text { Average Anglo- } \\
\text { American }\end{array}$ & 0.907 & 0.724 & 1.694 & 0.178 & 29.109 \\
\hline
\end{tabular}




\section{Figure 1}

European share in the total derivative market

Percentage of the open interest contracts (sum of interest rate, currency, and equity indexes) that are traded on European exchanges. Source: BIS.

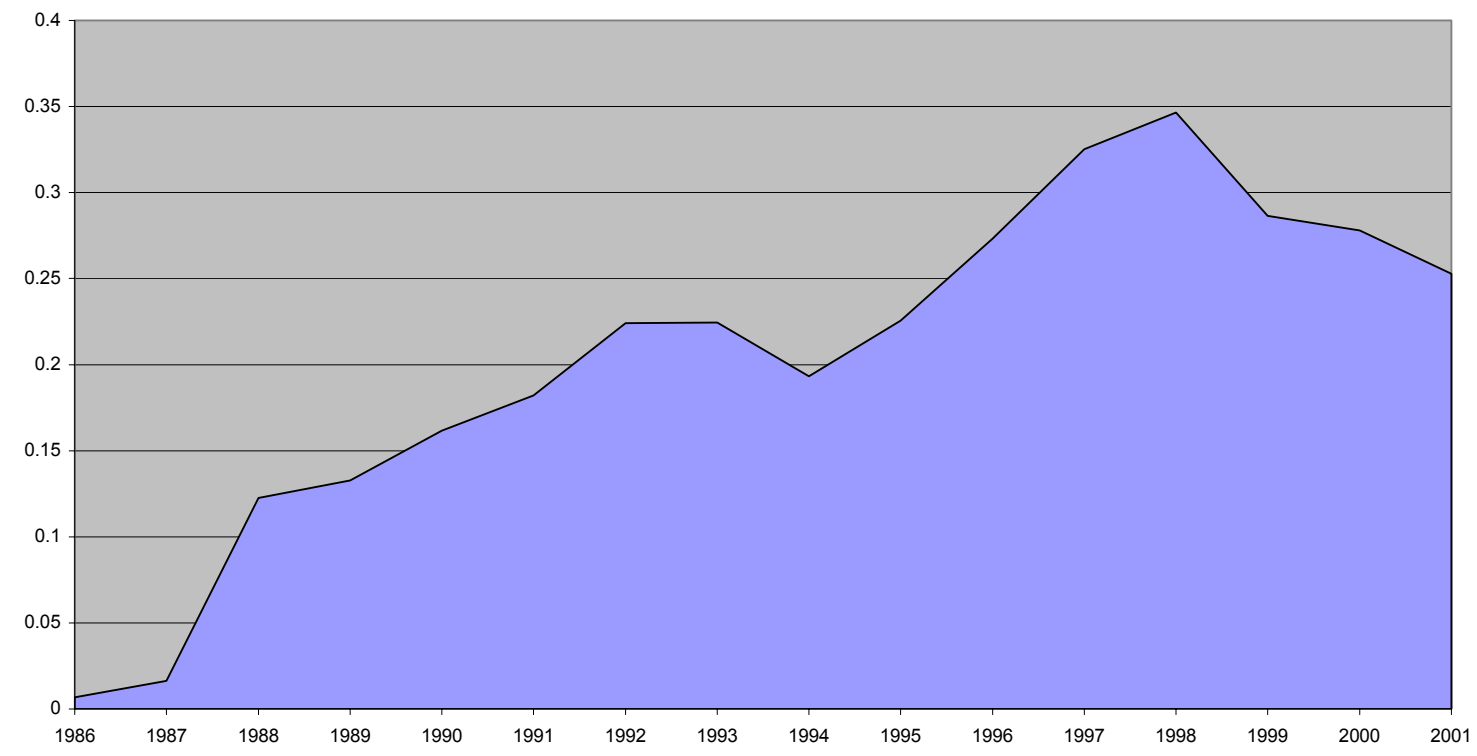


Figure 2

European share in the different derivative markets

Percentage of the open interest contracts that are traded on European exchanges. Source: BIS.

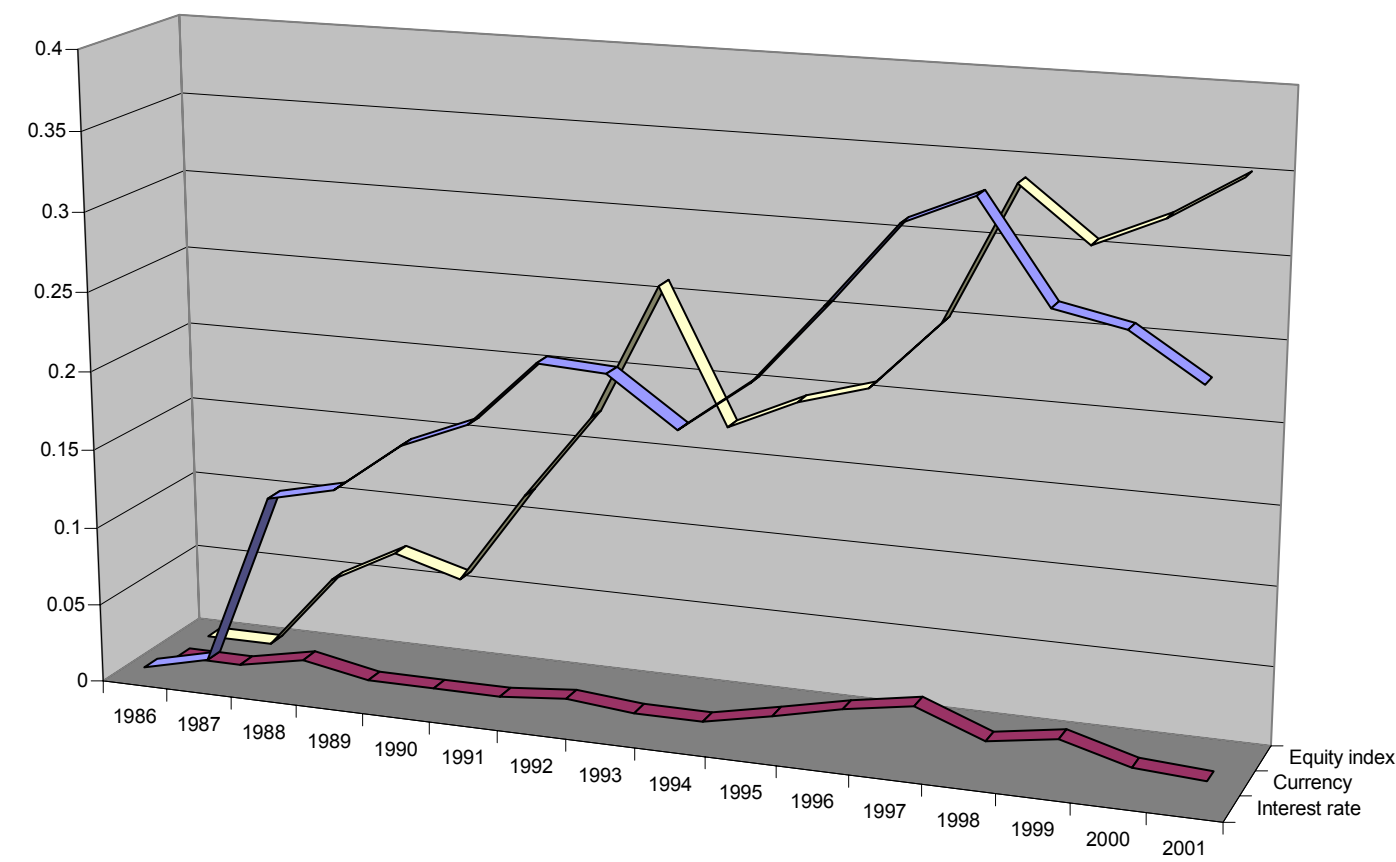




\section{Table 3}

\section{Evolution of Bank debt}

Bank loan to the private sector is the ratio of claims on private sector of deposit money banks (line 22d International Financial Statistics) and GDP. Source: IMF Financial Statistics.

$\begin{array}{lcccccccc} & 1980 & 1985 & 1990 & 1995 & 1998 & 1999 & 2000 & 2001 \\ \text { AUSTRIA } & 0.742 & 0.841 & 0.928 & 0.940 & . & 1.002 & 1.040 & 1.062 \\ \text { BELGIUM } & 0.272 & 0.248 & 0.353 & 0.747 & . & 0.817 & 0.792 & 0.771 \\ \text { DENMARK } & 0.244 & 0.300 & 0.520 & 0.310 & 0.351 & 0.347 & . & . \\ \text { FINLAND } & 0.462 & 0.601 & 0.860 & 0.620 & 0.520 & 0.539 & 0.534 & 0.576 \\ \text { FRANCE } & 0.731 & 0.764 & 0.960 & 0.869 & . & 0.821 & 0.864 & 0.898 \\ \text { GERMANY } & 0.864 & 0.953 & 1.006 & 1.031 & 1.186 & 1.178 & 1.207 & 1.210 \\ \text { GREECE } & 0.520 & 0.517 & 0.367 & 0.336 & 0.381 & 0.461 & 0.526 & 0.633 \\ \text { IRELAND } & 0.315 & 0.456 & 0.476 & 0.703 & 0.892 & 1.031 & 1.069 & 1.118 \\ \text { ITALY } & 0.555 & 0.506 & 0.565 & 0.575 & 0.589 & 0.711 & 0.770 & 0.795 \\ \text { LUXEMBOURG } & 1.210 & 0.978 & 1.243 & 0.976 & . & 1.075 & 1.099 & 1.373 \\ \text { NETHERLANDS } & 0.632 & 0.611 & 0.794 & 0.941 & . & 1.296 & 1.398 & 1.426 \\ \text { PORTUGAL } & 0.855 & 0.815 & 0.506 & 0.705 & 1.024 & 1.209 & 1.408 & 1.460 \\ \text { SPAIN } & & . & 0.831 & 0.770 & 0.925 & 0.923 & 1.012 & 1.059 \\ \text { SWEDEN } & 0.415 & 0.393 & 0.582 & 0.348 & 0.405 & 0.423 & 0.457 & . \\ \text { UK } & 0.276 & 0.472 & 1.158 & 1.153 & 1.183 & 1.212 & 1.320 & 1.385 \\ & & & & & & & & \\ \text { Euro area average } & 0.651 & 0.663 & 0.741 & 0.768 & 0.788 & 0.922 & 0.977 & 1.032 \\ \text { EU average } & 0.578 & 0.604 & 0.743 & 0.735 & 0.746 & 0.870 & 0.964 & 1.059 \\ & & & & & & & & \\ \text { US } & 0.354 & 0.371 & 0.430 & 0.436 & 0.470 & 0.474 & 0.493 & 0.503\end{array}$




\section{Table 4}

Increased importance of corporate debt

Domestic corporate debt outstanding divided by GDP. Source: BIS for the debt and IMF Financial Statistics for the GDP.

\begin{tabular}{|c|c|c|c|c|c|c|c|c|c|c|c|c|c|}
\hline & 1989 & 1990 & 1991 & 1992 & 1993 & 1994 & 1995 & 1996 & 1997 & 1998 & 1999 & 2000 & 2001 \\
\hline AUSTRIA & 0.018 & 0.017 & 0.016 & 0.014 & 0.017 & 0.019 & 0.021 & 0.017 & 0.019 & 0.020 & 0.019 & 0.017 & 0.016 \\
\hline BELGIUM & 0.078 & 0.073 & 0.070 & 0.067 & 0.065 & 0.065 & 0.065 & 0.066 & 0.065 & 0.064 & 0.075 & 0.072 & 0.080 \\
\hline DENMARK & 0.925 & 0.910 & 0.905 & 0.876 & 1.062 & 0.912 & 0.896 & 0.893 & 0.912 & 0.951 & 0.940 & 0.957 & 1.007 \\
\hline FINLAND & 0.099 & 0.103 & 0.103 & 0.092 & 0.094 & 0.074 & 0.057 & 0.056 & 0.047 & 0.048 & 0.061 & 0.060 & 0.056 \\
\hline FRANCE & 0.038 & 0.043 & 0.044 & 0.044 & 0.042 & 0.042 & 0.039 & 0.053 & 0.051 & 0.055 & 0.075 & 0.093 & 0.088 \\
\hline GERMANY & 0.001 & 0.001 & 0.004 & 0.006 & 0.005 & 0.003 & 0.002 & 0.003 & 0.004 & 0.004 & 0.007 & 0.013 & 0.020 \\
\hline GREECE & 0.052 & 0.054 & 0.043 & 0.048 & 0.042 & 0.042 & 0.025 & 0.008 & 0.008 & 0.008 & 0.003 & 0.002 & \\
\hline IRELAND & 0.020 & 0.026 & 0.033 & 0.047 & 0.058 & 0.041 & 0.033 & 0.021 & 0.050 & 0.060 & 0.074 & 0.097 & 0.105 \\
\hline ITALY & 0.005 & 0.004 & 0.003 & 0.002 & 0.002 & 0.004 & 0.004 & 0.004 & 0.005 & 0.005 & 0.010 & 0.024 & 0.061 \\
\hline \multicolumn{14}{|l|}{ LUXEMBOURG } \\
\hline NETHERLANDS & 0.031 & 0.033 & 0.031 & 0.031 & 0.031 & 0.033 & 0.033 & 0.036 & 0.038 & 0.043 & 0.067 & 0.125 & 0.136 \\
\hline PORTUGAL & 0.038 & 0.047 & 0.045 & 0.044 & 0.046 & 0.057 & 0.074 & 0.090 & 0.089 & 0.099 & 0.099 & 0.096 & 0.090 \\
\hline SPAIN & 0.081 & 0.105 & 0.090 & 0.092 & 0.093 & 0.077 & 0.063 & 0.057 & 0.052 & 0.056 & 0.067 & 0.058 & 0.072 \\
\hline SWEDEN & 0.450 & 0.483 & 0.504 & 0.558 & 0.592 & 0.524 & 0.493 & 0.511 & 0.458 & 0.437 & 0.407 & 0.333 & 0.283 \\
\hline UK & 0.035 & 0.032 & 0.030 & 0.032 & 0.039 & 0.041 & 0.044 & 0.046 & 0.057 & 0.081 & 0.102 & 0.130 & 0.154 \\
\hline Euro area average & 0.042 & 0.046 & 0.044 & 0.044 & 0.045 & 0.041 & 0.038 & 0.037 & 0.039 & 0.042 & 0.051 & 0.060 & 0.073 \\
\hline EU average & 0.134 & 0.138 & 0.137 & 0.139 & 0.156 & 0.138 & 0.132 & 0.133 & 0.132 & 0.138 & 0.143 & 0.148 & 0.167 \\
\hline US & 0.222 & 0.222 & 0.229 & 0.233 & 0.236 & 0.227 & 0.229 & 0.229 & 0.226 & 0.236 & 0.241 & 0.240 & 0.241 \\
\hline
\end{tabular}




\section{Table 5}

\section{Increased importance of international corporate debt}

International corporate debt outstanding by country of issuer divided by GDP. Source: BIS for the debt and IMF Financial Statistics for the GDP.

\begin{tabular}{|c|c|c|c|c|c|c|c|c|c|}
\hline & 1993 & 1994 & 1995 & 1996 & 1997 & 1998 & 1999 & 2000 & 2001 \\
\hline AUSTRIA & 0.033 & 0.034 & 0.033 & 0.028 & 0.027 & 0.026 & 0.024 & 0.022 & 0.021 \\
\hline BELGIUM & 0.005 & 0.004 & 0.008 & 0.008 & 0.008 & 0.009 & 0.010 & 0.008 & 0.023 \\
\hline DENMARK & 0.025 & 0.026 & 0.024 & 0.026 & 0.021 & 0.022 & 0.025 & 0.028 & 0.038 \\
\hline FINLAND & 0.038 & 0.025 & 0.021 & 0.017 & 0.030 & 0.025 & 0.033 & 0.049 & 0.066 \\
\hline FRANCE & 0.039 & 0.041 & 0.039 & 0.041 & 0.042 & 0.048 & 0.069 & 0.091 & 0.128 \\
\hline GERMANY & 0.003 & 0.004 & 0.004 & 0.004 & 0.006 & 0.006 & 0.010 & 0.021 & 0.023 \\
\hline GREECE & 0.026 & 0.025 & 0.023 & 0.020 & 0.017 & 0.018 & 0.024 & 0.032 & . \\
\hline IRELAND & 0.012 & 0.011 & 0.007 & 0.007 & 0.016 & 0.007 & 0.008 & 0.016 & 0.043 \\
\hline ITALY & 0.004 & 0.005 & 0.005 & 0.004 & 0.003 & 0.005 & 0.007 & 0.009 & 0.019 \\
\hline LUXEMBOURG & 0.055 & 0.045 & 0.055 & 0.114 & 0.118 & 0.104 & 0.098 & 0.084 & 0.107 \\
\hline NETHERLANDS & 0.034 & 0.036 & 0.035 & 0.041 & 0.043 & 0.056 & 0.069 & 0.141 & 0.147 \\
\hline PORTUGAL & 0.007 & 0.005 & 0.003 & 0.002 & 0.002 & 0.003 & 0.012 & 0.011 & 0.023 \\
\hline SPAIN & 0.006 & 0.005 & 0.005 & 0.005 & 0.007 & 0.008 & 0.017 & 0.028 & 0.033 \\
\hline SWEDEN & 0.033 & 0.024 & 0.023 & 0.017 & 0.019 & 0.027 & 0.044 & 0.053 & 0.075 \\
\hline UK & 0.044 & 0.043 & 0.045 & 0.045 & 0.054 & 0.065 & 0.083 & 0.107 & 0.106 \\
\hline Euro area average & 0.022 & 0.020 & 0.020 & 0.024 & 0.027 & 0.026 & 0.032 & 0.043 & 0.058 \\
\hline EU average & 0.024 & 0.022 & 0.022 & 0.025 & 0.028 & 0.028 & 0.035 & 0.047 & 0.061 \\
\hline US & 0.007 & 0.007 & 0.007 & 0.008 & 0.011 & 0.013 & 0.019 & 0.023 & 0.031 \\
\hline
\end{tabular}


Figure 3

The increase in securitization

New issues of Asset backed securities and mortgage backed securities placed in the Euromarket or in European domestic markets having underlying collateral from Europe. Source: ESF Securitisation Data Report.

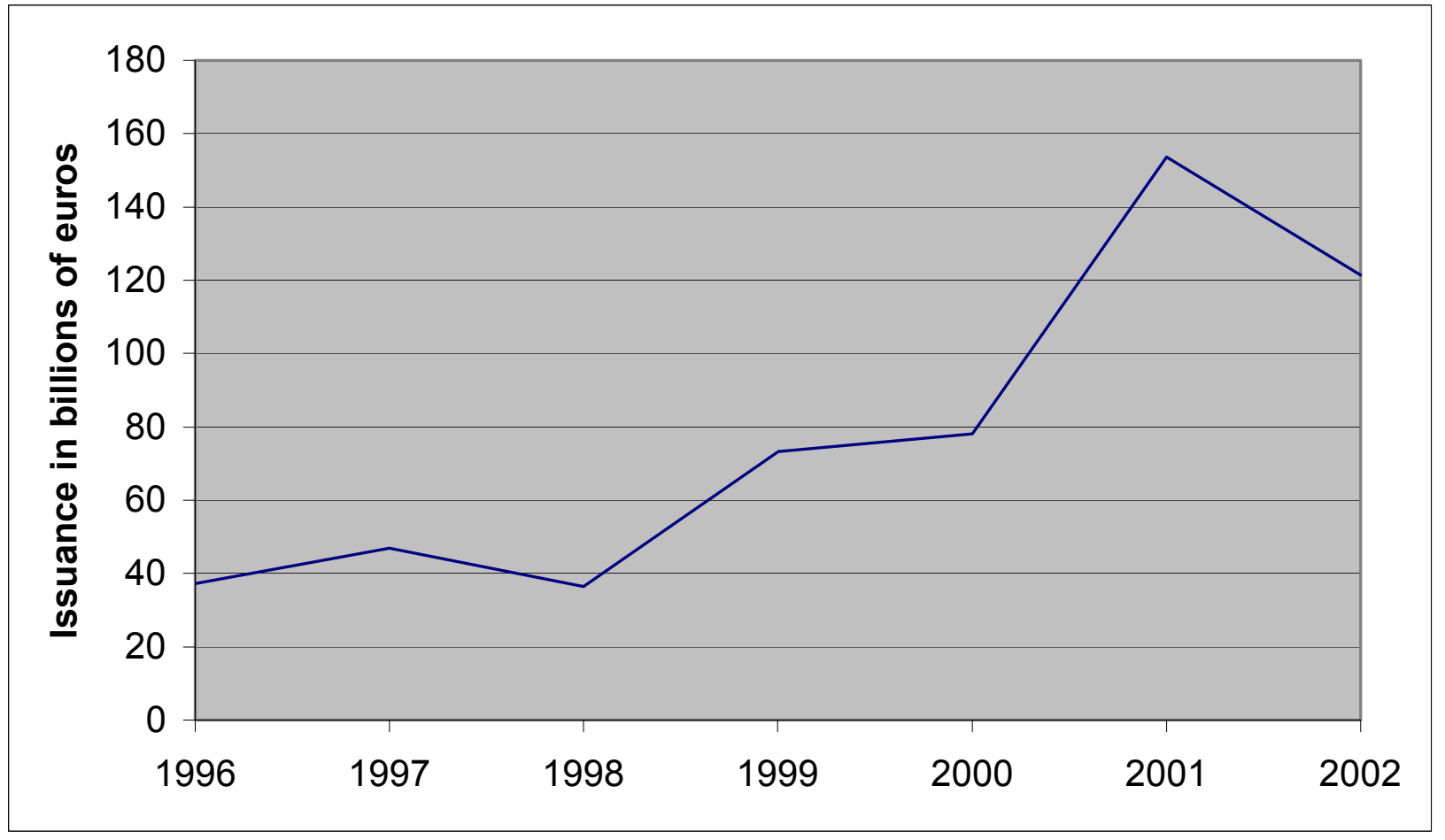




\section{Table 6}

\section{Introduction and Enforcement of the Insider Trading Law}

The first column reports the year legislation to curb insider trading was introduced, the second one the year the first case of prosecution took place. "No" means there has been no case of prosecution. Source: Bhattacharya and Daouk (2002).

$\begin{array}{lcc}\text { Country } & \begin{array}{c}\text { Year insider trading } \\ \text { law introduced }\end{array} & \begin{array}{c}\text { First time it } \\ \text { was enforced }\end{array} \\ \text { Austria } & 1993 & \text { No } \\ \text { Belgium } & 1990 & 1994 \\ \text { Denmark } & 1991 & 1996 \\ \text { Finland } & 1989 & 1993 \\ \text { France } & 1967 & 1975 \\ \text { Germany } & 1994 & 1995 \\ \text { Greece } & 1988 & 1996 \\ \text { Ireland } & 1990 & \text { No } \\ \text { Italy } & 1991 & 1996 \\ \text { Luxembourg } & 1991 & \text { No } \\ \text { Netherlands } & 1989 & 1994 \\ \text { Portugal } & 1986 & \text { No } \\ \text { Spain } & 1994 & 1998 \\ \text { Sweden } & 1971 & 1990 \\ \text { U.K. } & 1980 & 1981 \\ \text { U.S. } & 1934 & 1961\end{array}$




\section{Table 7}

\section{Concentration of the Banking Sector in 1930}

Source: Grossman (1994).

\begin{tabular}{|l|r|r|} 
Country & $\begin{array}{r}\text { Branches } \\
\text { per Bank }\end{array}$ & $\begin{array}{r}\text { Population per } \\
\text { Bank (000) }\end{array}$ \\
\hline Belgium & 14.16 & 92.6 \\
\hline Denmark & 3.06 & 19.6 \\
\hline France & 9.46 & 160.9 \\
\hline Germany & 3.06 & 176.1 \\
\hline Italy & 1.91 & 104.80 \\
\hline Netherlands & 24 & 1305.50 \\
\hline Spain & 5.08 & 105.90 \\
\hline Sweden & 33.83 & 204 \\
\hline U.K. & 613.44 & 2481.3 \\
\hline U.S. & 1.14 & 16.2 \\
\hline
\end{tabular}




\section{Table 8}

\section{Corporate Debt Before and After the Euro}

Net bond issues are computed as difference of the level of bond outstanding as reported by the BIS. We sum domestic corporate bonds and international corporate bonds issues by firms domiciled in the country and normalized by a country GDP. Source: BIS.

\section{Panel A: Summary Statistics}

$\begin{array}{lcccccc}\text { Variable } & \text { Mean } & \text { Median } & \text { St. Dev. } & \text { Min. } & \text { Max. } & \text { N } \\ \text { Net issues of domestic corporate debt } & 0.004 & 0.001 & 0.013 & -0.037 & 0.105 & 411 \\ \text { Net issues of int. corporate debt } & 0.004 & 0.001 & 0.010 & -0.025 & 0.072 & 292 \\ \text { Net issues of total corporate debt } & 0.009 & 0.004 & 0.020 & -0.034 & 0.129 & 258\end{array}$

Panel B: Regression Analysis

\begin{tabular}{|c|c|c|c|}
\hline Dependent variable: & $\begin{array}{l}\text { Net issues } \\
\text { of domestic } \\
\text { corp. debt }\end{array}$ & $\begin{array}{l}\text { Net issues } \\
\text { of intern. } \\
\text { corp. debt }\end{array}$ & $\begin{array}{l}\text { Net issues } \\
\text { of total } \\
\text { debt }\end{array}$ \\
\hline Euro dummy & $\begin{array}{c}0.006 \\
(0.003)\end{array}$ & $\begin{array}{c}0.007 \\
(0.003)\end{array}$ & $\begin{array}{c}0.018 \\
(0.005)\end{array}$ \\
\hline Year fixed effects & Yes & Yes & Yes \\
\hline Country fixed effects & Yes & Yes & Yes \\
\hline R-squared & 0.3608 & 0.2357 & 0.4741 \\
\hline $\mathrm{N}$ & 411 & 292 & 258 \\
\hline
\end{tabular}


Figure 4

Net bond issues around the introduction of the Euro

Net bond issues are computed as difference of the level of bond outstanding as reported by the BIS. We sum domestic corporate bonds and international corporate bonds issues by firms domiciled in the country and normalized by a country GDP.

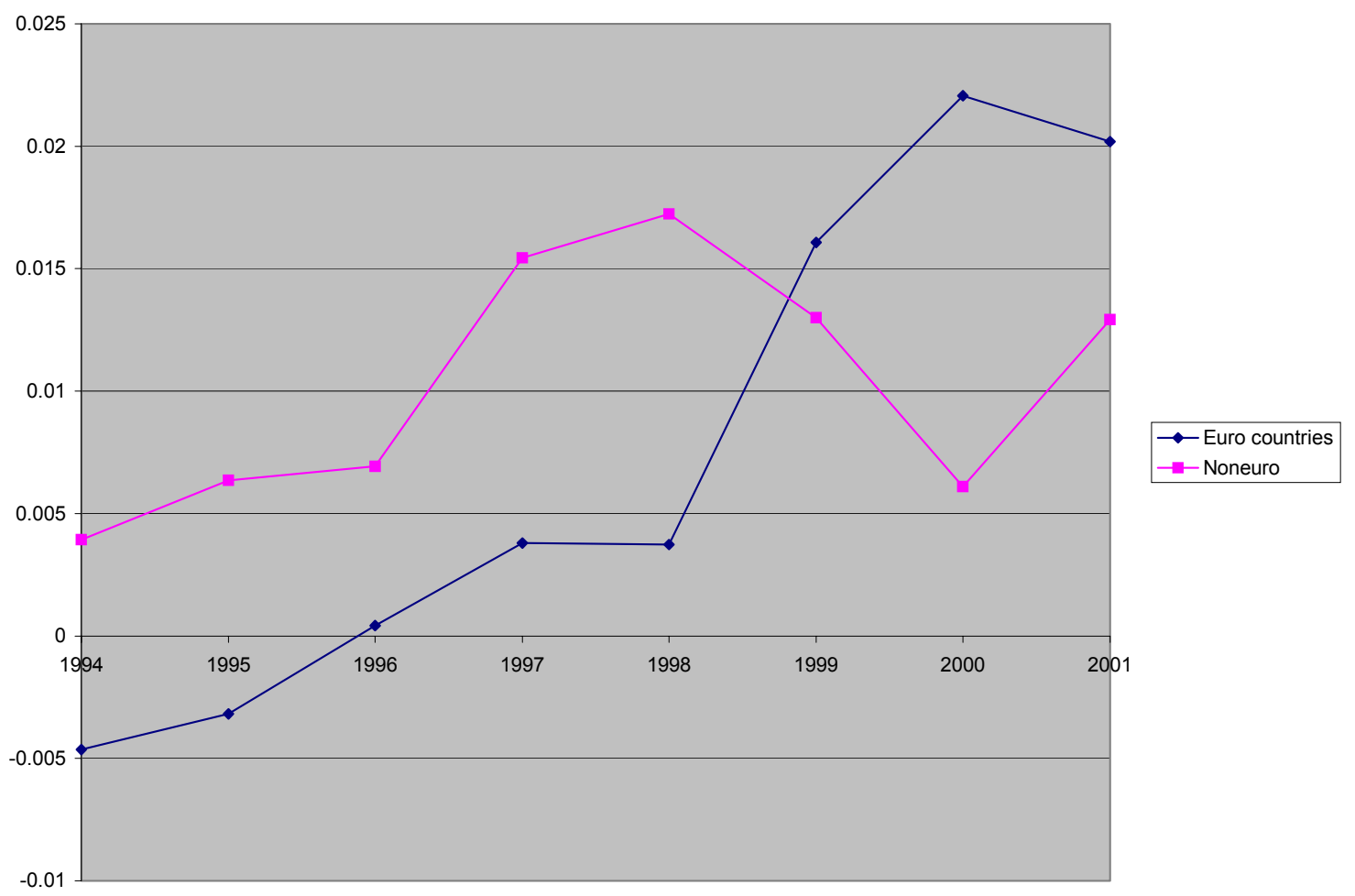




\section{Table 9}

\section{The North-South Institutional Divide}

Shareholders' rights is an index from 1 to 5 of the rights minority shareholders have against incumbents. Similarly creditor' rights is an index from 1 to 5 of the rights creditors have in bankruptcy. Both are from La Porta et al. (1998). Days to collect a check is the total number of days (completion of service, trial, and enforcement) it takes to collect the money on a bounced check. Source: Djankov et al. (2002). Days to evict a tenant is the total number of days (completion of service, trial, and enforcement) it takes to evict a tenant that does not pay. Source: Djankov et al. (2002). Judicial efficiency is an assessment, produced by country risk rating agency Business International Corp, of the "efficiency and integrity of the legal environment as it affects business, particularly foreign firms". The scale is from 0 to 10 and the source is La Porta et al. (1998). Rule of law is the "assessment of the law and order tradition in the country produced by the country risk rating agency International Country Risk (ICR). Scale from zero to 10, with lower scores for less tradition for law and order, source: La Porta et al. (1998). Corruption is an index of the pervasiveness of corruption (higher number means less corruption), source: La Porta et al. (1998). Tax compliance is the "assessment of the level of tax compliance. Scale from 0 to 6 where higher scores indicate higher compliance. Data is for 1995. The source is the Global Competitiveness Report 1996 as reported in La Porta et al. 1999. The value of control is the premium paid to acquire a controlling block lock as a percentage of the value of equity. The block premia is computed taking the difference between the price per share paid for the control block and the exchange price two days after the announcement of the control transaction, dividing it by the exchange price two days after the announcement and multiplying the ratio by the proportion of cash flow rights represented in the controlling block. Source: Dyck and Zingales (2003). The average number of employees is the ratio between the total number of workers and the total number of firms in 1992-92. Source Kumar et al. (2000).

AUSTRIA BELGIUM DENMARK FINLAND

FRANCE GERMANY GREECE

IRELAND

ITALY

LUXEMBOURG

NETHERLANDS

PORTUGAL

SPAIN

SWEDEN

UK

Euro area average

EU average

Southern Europe

Northern Europe

US
Shareholders' Creditors' rights Days to collect Days to evict
a check a tenant
Efficiency of judicial system of law

$\begin{array}{cc}434 & 547 \\ 120 & 120 \\ 83 & 225 \\ 240 & 120 \\ 181 & 226 \\ 154 & 331 \\ 315 & 247 \\ 130 & 121 \\ 645 & 630 \\ 210 & 380 \\ 39 & 52 \\ 420 & 330 \\ 147 & 183 \\ 190 & 160 \\ 101 & 115 \\ & \\ 252.92 & 264.27 \\ 227.27 & 243.36 \\ 381.75 & 347.50 \\ 171.09 & 201.70\end{array}$

54

$$
\begin{gathered}
9.50 \\
9.50 \\
10.00 \\
10.00 \\
8.00 \\
9.00 \\
7.00 \\
8.75 \\
6.75 \\
\text { na } \\
10.00 \\
5.50 \\
6.25 \\
10.00 \\
10.00 \\
\\
8.20 \\
8.59 \\
\\
6.38 \\
9.48
\end{gathered}
$$$$
10.00
$$$$
10.00
$$$$
10.00
$$

49$$
10.00
$$$$
10.00
$$$$
8.98
$$$$
\begin{array}{r}
9.23 \\
6.18
\end{array}
$$$$
6.18
$$$$
7.80
$$$$
8.33
$$$$
\text { na }
$$$$
\begin{array}{r}
10.00 \\
8.68
\end{array}
$$$$
8.68
$$$$
7.80
$$$$
10.00
$$$$
8.57
$$$$
8.82
$$$$
8.97
$$

10.00

10.00
5
1
Corruption

\subsection{0}

$$
10.00
$$$$
\begin{aligned}
& 8.57 \\
& 8.82
\end{aligned}
$$$$
\begin{gathered}
8.82 \\
10.00
\end{gathered}
$$$$
\begin{aligned}
& 10.00 \\
& 10.00
\end{aligned}
$$$$
9.05
$$$$
8.93
$$$$
7.27
$$$$
8.52
$$$$
6.13
$$$$
\text { na }
$$$$
10.00
$$$$
7.38
$$$$
7.38
$$$$
10.00
$$
3.60 2.27 2.27
3.70 3.53

3.86

3.41

2.36

3.55

1.77

$\begin{array}{ccc}54 & 0.38 & \text { na } \\ 61 & \text { na } & 12.5 \\ 62 & 0.08 & 11.5 \\ 77 & 0.02 & 5.7 \\ 69 & 0.02 & 7.1 \\ 62 & 0.10 & 10.3 \\ 55 & \text { na } & \text { na } \\ \text { na } & \text { na } & \text { na } \\ 62 & 0.37 & 4.4 \\ \text { na } & \text { na } & \text { na } \\ 64 & 0.02 & 11.9 \\ 36 & 0.20 & 6.0 \\ 64 & 0.04 & 4.0 \\ 83 & 0.07 & 10.4 \\ 78 & 0.01 & 9.6 \\ & & \\ 60.40 & 0.14 & 7.7 \\ 63.62 & 0.12 & 7.8 \\ 54.25 & 0.20 & 4.8 \\ 67.78 & 0.09 & 9.9 \\ 71 & 0.01 & \text { na }\end{array}$

